\title{
Lycopene-rich extract from red guava (Psidium guajava L.) displays cytotoxic effect against human breast adenocarcinoma cell line MCF-7 via an apoptotic-like pathway
}

\author{
Raimunda C. dos Santos ${ }^{\mathrm{a}}$, Alicia S. Ombredane ${ }^{\mathrm{b}}$, Jéssica Maria T. Souza ${ }^{\mathrm{a}}$, \\ Andreanne G. Vasconcelos ${ }^{\mathrm{a}}$, Alexandra Plácido ${ }^{\mathrm{c}}$, Adriany das G.N. Amorim ${ }^{\mathrm{a}}$, \\ Eder Alves Barbosa ${ }^{\mathrm{d}, \mathrm{e}}$, Filipe C.D.A. Lima ${ }^{\mathrm{f}}$, Cristina D. Ropke ${ }^{\mathrm{g}}$, Michel M.M. Alves ${ }^{\mathrm{h}}$, \\ Daniel D.R. Arcanjo ${ }^{\mathrm{h}}$, Fernando A.A. Carvalho ${ }^{\mathrm{h}}$, Cristina Delerue-Matos ${ }^{\mathrm{c}}$, Graziella A. Joanitti ${ }^{\mathrm{b}, \mathrm{i}}$, \\ José Roberto de S.A. Leite ${ }^{\mathrm{j}, *}$ \\ ${ }^{\text {a }}$ Núcleo de Pesquisa em Biodiversidade e Biotecnologia, Biotec, Campus Ministro Reis Velloso, Universidade Federal do Piauí, Parnaíba, PI, Brazil

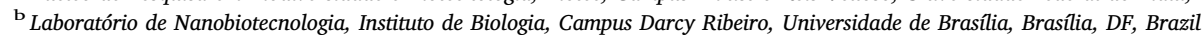 \\ ${ }^{\mathrm{c}}$ REQUIMTE/LAQV, Instituto Superior de Engenharia do Porto, Instituto Politécnico do Porto, Porto, Portugal \\ d Laboratório de Síntese e Análise de Biomoléculas, LSAB, Instituto de Química, Campus Darcy Ribeiro, Universidade de Brasília, Brasília, DF, Brazil \\ e Laboratório de Espectrometria de Massa, Embrapa Recursos Genéticos e Biotecnologia, Brasília, DF, Brazil \\ ${ }^{\mathrm{f}}$ Instituto Federal de Educação Ciência e Tecnologia de São Paulo, Matão, SP, Brazil \\ ${ }^{\mathrm{g}}$ Phytobios LTDA, Barueri, SP, São Paulo, Brazil

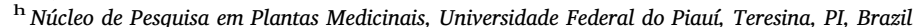 \\ ${ }^{\text {i } C a m p u s ~ C e i l a ̂ n d i a, ~ C e n t r o ~ M e t r o p o l i t a n o, ~ U n i v e r s i d a d e ~ d e ~ B r a s i ́ l i a, ~ C e i l a ̂ n d i a, ~ B r a s i ́ l i a, ~ D F, ~ B r a z i l ~}$ \\ j Área de Morfologia, Faculdade de Medicina, Campus Darcy Ribeiro, Universidade de Brasília, Brasília, DF, Brazil
}

\begin{abstract}
A B S T R A C T
This study investigated a lycopene-rich extract from red guava (LEG) for its chemical composition using spectrophotometry, mass spectrometry, attenuated total reflectance-fourier transform infrared spectroscopy (ATRFTIR), and computational studies. The cytotoxic activity of LEG and the underlying mechanism was studied in human breast adenocarcinoma cells (MCF-7), murine fibroblast cells (NIH-3 T3), BALB/c murine peritoneal macrophages, and sheep blood erythrocytes by evaluating the cell viability with 3-(4,5-dimethylthiazol-2-yl)2,5-diphenyltetrazolium bromide (MTT) method and flow cytometry. Spectrophotometry analysis showed that LEG contained $20 \%$ of lycopene per extract dry weight. Experimental and theoretical ATR-FTIR suggests the presence of lycopene, whereas MS/MS spectra obtained after fragmentation of the molecular ion $[\mathrm{M}]^{+\cdot}$ of 536.4364 show fragment ions at $m / z 269.2259,375.3034,444.3788$, and 467.3658 , corroborating the presence of lycopene mostly related to all-trans configuration. Treatment with LEG (1600 to $6.25 \mu \mathrm{g} / \mathrm{mL}$ ) for 24 and $72 \mathrm{~h}$ significantly affected the viability of MCF-7 cells (mean half maximal inhibitory concentration $\left[\mathrm{IC}_{50}\right]=29.85$ and $5.964 \mu \mathrm{g} / \mathrm{mL}$, respectively) but not $\mathrm{NIH}-3 \mathrm{~T} 3$ cells $\left(\mathrm{IC}_{50}=1579\right.$ and $911.5 \mu \mathrm{g} / \mathrm{mL}$, respectively). Furthermore LEG at concentrations from 800 to $6.25 \mu \mathrm{g} / \mathrm{mL}$ presented low cytotoxicity against BALB/c peritoneal macrophages ( $\mathrm{IC}_{50} \geq 800 \mu \mathrm{g} / \mathrm{mL}$ ) and no hemolytic activity. LEG (400 and $800 \mu \mathrm{g} / \mathrm{mL}$ ) caused reduction in the cell proliferation and induced cell cycle arrest, DNA fragmentation, modifications in the mitochondrial membrane potential, and morphologic changes related to granularity and size in MCF-7 cells; however, it failed to cause any significant damage to the cell membrane or display necrosis or traditional apoptosis. In conclusion, LEG was able to induce cytostatic and cytotoxic effects on breast cancer cells probably via induction of an apoptotic-like pathway.
\end{abstract}

Keywords:

Carotenoid

Antioxidant

Breast cancer

Cytotoxicity

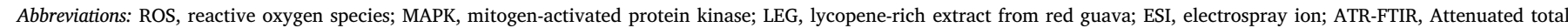

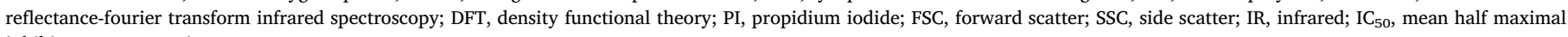
inhibitory concentration 


\section{Introduction}

Psidium guajava L., popularly known as red guava or guava tree, is a tropical plant and its fruit is widely consumed because of its nutritional benefits and pleasant taste (Lee, Choi, Cho, \& Kim, 2010). Medical and pharmacological studies have demonstrated the important biological activity of this plant against various diseases, including cancer. The acetone extracts of guava branch exerted cytotoxic effects against HT29 human colon cancer cells, as assessed by the 3-(4,5-dimethylthiazol2-yl)-2,5-diphenyltetrazolium bromide (MTT) reduction assay (Lee \& Park, 2010). Furthermore, the hexane fraction of guava leaf was shown to induce potent cytotoxic and apoptotic effects in PC-3 human prostate cancer cell lines via mechanisms related to the protein kinase B (AKT)/ mechanistic target of rapamycin (mTOR)/S6 kinase beta-1 (S6 K1) and mitogen-activated protein kinase (MAPK) signaling pathways (Ryu et al., 2012).

Red guava is rich in proteins, lipids, dietary fibers, minerals, and functional compounds such as anthocyanins and carotenoids (Dalla Nora et al., 2014). Carotenoids, natural pigments found in vegetables and fruits, are used as food additives and possess important physiological properties (Vargas-Murga, de Rosso, Mercadante, \& OlmedillaAlonso, 2016). One of the most important carotenoids with healthbeneficial effects present in guava fruits is lycopene.

Lycopene is an open chain polyunsaturated hydrocarbon with a molecular formula of $\mathrm{C}_{40} \mathrm{H}_{56}$ and theoretical atomic mass of 536.4376 . Lycopene contains 11 conjugated and 2 non-conjugated double bonds and is lipophilic in nature (Ganesh, Lakshmi, \& Chandy, 2016). Both cis and trans isomeric forms of lycopene are found in nature; all-trans, 5-cis, 9-cis, 13-cis, and 15-cis isoforms are the most common forms of lycopene.

The conjugated double bonds of lycopene make it a powerful antioxidant, enabling it to scavenge singlet oxygen and various radical cations or other reactive oxygen species (ROS) such as superoxide, peroxyl, and hydroxyl radicals (Böhm, 2012; Bramley, 2000; Di Mascio, Kaiser, \& Sies, 1989). The antioxidant property is responsible for its beneficial effects on human health.

Several studies have demonstrated the neuroprotective, hepatoprotective, cardioprotective, antifungal, anti-inflammatory, and anticancer activities of lycopene (Bandeira et al., 2017; Choi \& Lee, 2015; Hu et al., 2017; Mariani et al., 2014; Ojha et al., 2013; Pinto, RodríguezGaldón, Cestero, \& Macías, 2013; Shen et al., 2014; Vasconcelos et al., 2017). Lycopene pretreatment at various doses significantly delayed tumor formation and growth, thereby reducing skin carcinogenesis in female ICR mice (Shen et al., 2014). Furthermore, lycopene treatment inhibited the formation of ROS and malondialdehyde, prevented the loss of glutathione, and affected the activities of several antioxidant enzymes in the mouse skin (Shen et al., 2014). Lycopene inhibits cell proliferation, arrests cell cycle in different phases, and increases apoptosis in breast, colon, and prostate cancer lines (Teodoro et al., 2012).

Cancer is characterized by a disordered growth of cells, which invade tissues and organs and spread to other regions of the body. Breast cancer is one of the most prevalent forms of cancer worldwide and its treatment comprises breast-conserving surgery and, in some cases, mastectomy, owing to large or multiple tumors, reluctance to undergo radiation therapy, or fear of recurrence (DeSantis et al., 2014). Thus, preventive approaches through the consumption of functional foods have become very important.

This study supports the potential application of the lycopene-rich extract from red guava (LEG) as a natural, accessible, and advantageous source with important roles in the prevention and treatment of breast cancer.

\section{Materials and methods}

\subsection{Chemicals and reagents}

Ethanol, methanol, formic acid, lycopene standard from tomato, MTT solution, penicillin, streptomycin, Roswell Park Memorial Institute (RPMI)-1640 medium, and dimethyl sulfoxide were purchased from Sigma-Aldrich Chemical Co. (St. Louis, MO, USA) and chloroform, from Dinâmica ${ }^{\circledR}$ Química Contemporânea Ltda (Brazil). Dimethyl sulfoxide (DMSO) was used to reconstitute LEG for biological assays, and phosphate-buffered saline (PBS) was used for dilutions. Thiopental and lidocaine were obtained from Syntec Co. (Santana de Parnaíba, SP, Brazil). Dulbecco's modified Eagle's medium (DMEM) was supplied by Life Technologies Corporation (Carlsbad, CA, USA).

\subsection{Extraction and quantification}

Lycopene-rich extract from red guava was obtained in accordance with the methodology developed by Amorim, Ropke, and Leite (2016) detailed in the patent $n^{\circ}$ BR102016030594-2, with some modifications. Red guava, originating from the organic production in the region of Tabuleiros Litorâneos, Parnaíba city, State of Piauí, Brazil, was purchased from a local market. The fruits $(500 \mathrm{~g})$, in high degree of maturation, were subjected to thermal treatment (freezing followed heating). The extraction with organic solvent (ethanol) was carried out with constant stirring until the extraction end. The extract was dried under vacuum of 175 mbar at room temperature (rotary-evaporator R215, Buchi, Switzerland). All steps were performed under dim light, while the final step of the process was carried out under nitrogen atmosphere. LEG was quantified in terms of the lycopene content and subjected to chemical and biological analyses.

Lycopene quantification in the extract was performed with a UV-Vis Shimadzu UV-1800 spectrophotometer (Tokyo, Japan). An external lycopene standard from tomato (Sigma-Aldrich) dissolved in chloroform and diluted in ethanol (1:20 ratio, chloroform:ethanol) at concentrations from 1 to $10 \mathrm{mg} / \mathrm{L}$ was used for the construction of the calibration curve. The absorbance spectra of LEG was obtained by scanning in the region of wavelength $(\lambda)$ between 600 and $350 \mathrm{~nm}$ against ethanol blank scanned in the region of wavelength $(\lambda)$ between 1100 and $190 \mathrm{~nm}$. Measurements at $471 \mathrm{~nm}$ wavelength were chosen for the quantitative analysis based on the maximum absorbance band observed by spectrophotometric scan and according to what has been previously reported in the literature (Obermüller-Jevic et al., 2003).

\subsection{Chemical studies}

\subsubsection{Mass spectrometry analyses}

High resolution mass spectrometry was used to identify the presence of lycopene in LEG. A fraction of the sample previously dissolved in chloroform was mixed in a buffer containing $0.1 \%$ formic acid in methanol:water (1:1) to obtain a solution equivalent to $5 \mathrm{ppm}$ concentration. The samples were directly injected under a flow rate of $180 \mu \mathrm{L} / \mathrm{h}$ in an Impact II mass spectrometer (Bruker, Daltonics) with an electrospray ion (ESI) source and operating in the positive mode. General parameters were as follows: temperature of dry gas of $200{ }^{\circ} \mathrm{C}$ and flow rate of $4 \mathrm{~L} / \mathrm{min}$, nebulizer pressure at 0.3 bars, capillary potential of $4.5 \mathrm{KV}$, and plate offset of $-500 \mathrm{~V}$. The full scan acquisition was set for a mass range of $m / z 50$ to 1500 . For precursor ion fragmentation (MS/MS), nitrogen was used as the collision gas at an energy of $15 \mathrm{eV}$. The mass spectrometer was controlled by OTOFControl 3.2 software and the analysis was performed using DataAnalysis 4.3 software. Before the acquisitions, mass spectrometer was calibrated using a solution of sodium formate $(10 \mathrm{mM})$. 


\subsubsection{Attenuated total reflectance-fourier transform infrared spectroscopy} (ATR-FTIR) experimental studies

We used ATR-FTIR to investigate the composition of LEG and for identification of lycopene. LEG was initially dried using nitrogen as a drying gas. FTIR was performed using a Thermo Nicolet 6700 Spectrophotometer, potassium bromide beam splitter, and deuterated triglycine sulfate detector. ATR technique in the spectral range from 4000 to $650 \mathrm{~cm}^{-1}$ was performed for each spectrum at a spectral resolution of $4 \mathrm{~cm}^{-1}$ and 32 scans. ATR accessory used a three-reflection diamond crystal plate providing a three-fold increase in the sample response as compared with the standard single-reflection crystal plate.

\subsection{Computational studies}

Theoretical simulations were carried out within the density functional theory (DFT) using the software Gaussian 09 (Frisch et al., 2009). Exchange-correlation functional B3LYP and the basis set 6-311 g (d,p) were employed (C. Lee, Yang, \& Parr, 1988). All-trans-lycopene, 5-cislycopene, and 13-cis-lycopene isomers were structurally optimized, minimizing the interaction forces between the atoms. A scaling factor of 0.952 was applied to correct DFT vibrational deviation, as discussed by Alecu, Zheng, Zhao, and Truhlar (2010). These calculations were simulated at vacuum conditions and without temperature effects, as this setup showed fairly good agreement between theoretical and experimental vibrational spectra for organic molecules (Bento et al., 2009; Cunha et al., 2012; Cunha et al., 2014; Marenich, Ho, Coote, Cramer, \& Truhlar, 2014; Rocha et al., 2016; Véras et al., 2013).

\subsection{Biological studies}

\subsubsection{Animals}

Ten male and female BALB/c mice (20-30 g, 4-5-week old), obtained from the Medicinal Plants Research Center bioterium of the Federal University of Piauí (Brazil), were used for cell viability assay. The animals were maintained at a temperature of $25 \pm 1{ }^{\circ} \mathrm{C}$ in a 12 -h light/dark cycle and supplied with water and food ad libitum. An anesthesia overdose by intraperitoneal injection of a mixture of thiopental $(150 \mathrm{mg} / \mathrm{kg})$ and lidocaine $(10 \mathrm{mg} / \mathrm{kg})$ was used to euthanize the animals. Macrophages were collected from the peritoneal cavities and cultivated in RPMI-1640 medium (20\% heat-inactivated fetal bovine serum [FBS], $100 \mathrm{U} / \mathrm{mL}$ penicillin, and $100 \mu \mathrm{g} / \mathrm{mL}$ streptomycin at $37^{\circ} \mathrm{C}$ and $5 \% \mathrm{CO}_{2}$ ). In addition, red blood cells were obtained by centrifugation of sheep blood ( 9 month-old) for red blood cell viability. The sheep was obtained from the Centre for Agrarian Sciences of Federal University of Piauí (Brazil).

All procedures were performed after receiving approval from the Animal Experimentation Ethics Committee of UFPI (permission No. 008/2012) and in accordance with the Brazilian Federal Council on Veterinary Medicine (CFMV) resolution 1000 (May 11, 2012) and CONCEA guidelines for the practice of euthanasia.

\subsubsection{MCF-7 and NIH-3 T3 cell culture}

Human breast adenocarcinoma cells (MCF-7) and murine fibroblast cells (NIH-3 T3) were obtained from the American Type Culture Collection (ATCC) and cell bank of Rio de Janeiro (Brazil), respectively. Both cell lines were grown in DMEM supplemented with $10 \%$ of heatinactivated FBS (Life, USA) and 1\% of antibiotic solution (100 IU/mL penicillin and $100 \mu \mathrm{g} / \mathrm{mL}$ streptomycin) at $37^{\circ} \mathrm{C}$ and $5 \% \mathrm{CO}_{2}$ in a humidified atmosphere.

\subsubsection{Cell treatment}

For the viability assay, macrophages were seeded at a density of $2 \times 10^{5}$ cells in RPMI-1640 in a 96-well culture plate for $4 \mathrm{~h}$ at $37^{\circ} \mathrm{C}$. Cells were washed twice with RPMI-1640 and treated with LEG in 1\% DMSO at concentrations ranging from 800 to $6.25 \mu \mathrm{g} / \mathrm{mL}$. DMSO was used as a control. The plates were incubated for $48 \mathrm{~h}$ at $37^{\circ} \mathrm{C}$.
MCF-7 and NIH-3 T3 cells were seeded into 96-well culture plates at a density of $3 \times 10^{3}$ cells in DMEM medium and incubated overnight at $37{ }^{\circ} \mathrm{C}$. The medium was changed and cells treated with various concentrations of LEG reconstituted in 1\% DMSO (1600 to $6.25 \mu \mathrm{g} / \mathrm{mL}$ ). DMSO was used as a control. The plates were incubated for 24 and $72 \mathrm{~h}$ at $37^{\circ} \mathrm{C}$.

For flow cytometry experiments, MCF-7 cells were plated into 12 well culture plates at a density of $5 \times 10^{4}$ cells. After incubation for $24 \mathrm{~h}$ at $37^{\circ} \mathrm{C}$, the cells were incubated with $1 \mathrm{~mL}$ of LEG at 400 and $800 \mu \mathrm{g} / \mathrm{mL}$ concentrations. Cells incubated with DMSO $(<1 \%)$ and hydrogen peroxide $\left(\mathrm{H}_{2} \mathrm{O}_{2}, 1 \mathrm{mM}\right)$ were used as controls. After 24- and 72-h treatment, the cells were harvested by trypsinization with $5 \mathrm{~min}$ of exposure to trypsin (Life, USA) at $37^{\circ} \mathrm{C}$. Trypsin was neutralized with the addition of the complete culture media and the cells were centrifuged at $3083 \times g$ for $5 \mathrm{~min}$ at $4{ }^{\circ} \mathrm{C}$.

\subsubsection{Cell viability assay of MCF-7 and NIH-3 T3 cells}

Cell viability assay was performed using MTT dye reduction method, which is based on the reduction of tetrazolium derivatives in living cells by mitochondrial dehydrogenases, thereby allowing the estimation of the metabolic activity of cells. This assay evaluates cell viability and proliferation as parameters for the estimation of cell survival and growth (Śliwka et al., 2016). After 24 and $72 \mathrm{~h}$ of incubation, $15 \mu \mathrm{L}$ of MTT solution $(5 \mathrm{mg} / \mathrm{mL}$ in phosphate buffer) was added in each well and the plates were incubated for $2 \mathrm{~h}$ at $37^{\circ} \mathrm{C}$. The medium was discarded and $100 \mu \mathrm{L}$ of DMSO was added to each well. The absorbance was monitored using a spectrophotometer with a microplate reader at $595 \mathrm{~nm}$ wavelength (Molecular Devices, USA). Data are representatives of three independent experiments.

\subsubsection{Macrophages viability assay}

The cytotoxicity of LEG on macrophages was assessed by MTT assay. After $48 \mathrm{~h}$ of incubation with LEG at concentrations ranging from 6.25 to $800 \mu \mathrm{g} / \mathrm{mL}$, cells were treated with $10 \mu \mathrm{L}$ of MTT diluted in RPMI medium at $5 \mathrm{mg} / \mathrm{mL}$ concentration for $4 \mathrm{~h}$ at $37^{\circ} \mathrm{C}$. Following incubation, the supernatant was discarded and $100 \mu \mathrm{L}$ of DMSO was added to each well. The plates were agitated for about $30 \mathrm{~min}$ on a Kline agitator (model AK 0506) at room temperature until formazan was completely dissolved. The absorbance of the samples was measured at $550 \mathrm{~nm}$ wavelength using a plate reader.

\subsubsection{Plasma membrane integrity and cell count}

The cell membrane integrity of MCF-7 cells was measured by trypan blue assay to evaluate the mechanism of action of LEG on cancer cells. Cells with undamaged membrane fail to uptake the dye, while those with disrupted membrane are positively stained with the dye (Joanitti, Azevedo, \& Freitas, 2010). Briefly, cells were exposed to 400 and $800 \mu \mathrm{g} / \mathrm{mL}$ of LEG for 24 and $72 \mathrm{~h}$. Cells were trypsinized and centrifuged at $3083 \times g$ for $5 \mathrm{~min}$ at $4{ }^{\circ} \mathrm{C}$. The pellet was resuspended in $100 \mu \mathrm{L}$ of $1 \times$ PBS and $10 \mu \mathrm{L}$ of cells were treated with $20 \mu \mathrm{L}$ of trypan blue solution $(0.4 \%$ in phosphate buffer; Sigma, EUA). Cells were counted using a Neubauer chamber and classified as those with disrupted or undamaged cell membrane.

\subsubsection{DNA fragmentation assay and cell cycle}

To elucidate the mechanism underlying the effect of LEG, DNA fragmentation and cycle cell assays were performed. MCF-7 cells were resuspended into $1 \mathrm{~mL}$ of cold ethanol $(70 \%)$ and stored at $-20{ }^{\circ} \mathrm{C}$ for $24 \mathrm{~h}$. After incubation, cells were washed twice with $1 \times$ PBS and treated with $100 \mu \mathrm{L}$ RNAse $(50 \mu \mathrm{M})$ for $30 \mathrm{~min}$ at $37^{\circ} \mathrm{C}$ in the dark. In the subsequent steps, cells were treated with $100 \mu \mathrm{L}$ propidium iodide (PI, $20 \mu \mathrm{g} / \mathrm{mL}$; Probes, Thermo Fisher, EUA) dissolved in $1 \times$ PBS for $30 \mathrm{~min}$ at room temperature in the dark. DNA fragmentation and cell cycle were analyzed using a flow cytometer (BD FACSVerse ${ }^{\mathrm{TM}}$, USA). A total of 10.000 events were collected per sample. 
2.5.8. Mitochondrial membrane potential and MCF-7 morphologic aspects

The mitochondrial membrane potential analysis was performed to evaluate the mechanism associated with apoptosis using rhodamine 123 , a cationic fluorescent probe that specifically accumulates in the mitochondria owing to the negative transmembrane potential of mitochondria in living cells (Carvalho et al., 2015; Ronot, Benel, Adolphe, \& Mounolou, 1986). MCF-7 cells were washed twice in $1 \times$ PBS, followed by their treatment with $300 \mu \mathrm{L}$ rhodamine $123(5 \mu \mathrm{g} / \mathrm{mL}$ in $1 \times$ PBS; Thermo Fisher, USA) for $15 \mathrm{~min}$ at room temperature in the dark. Following incubation, cells were washed twice with PBS and analyzed using the flow cytometer. A total of 10.000 events were collected per sample. Parameters related to the size and granularity of treated cells were obtained using forward scatter (FSC) and side scatter (SSC) channels, respectively.

\subsubsection{Annexin-V fluorescein isothiocyanate (FITC)/PI staining}

The Annexin-V FITC/PI staining was used to distinguish apoptotic cells from necrotic cells. The recombinant Annexin V conjugated to FITC dye detects the externalization of phosphatidylserine in apoptotic cells. On the other hand, PI-a popular red-fluorescent intercalating nucleic acid-is impermeable in living cells and is used to detect necrotic cells. After 24 and $72 \mathrm{~h}$ of incubation, cells were washed with PBS and resuspended in $100 \mu \mathrm{L}$ of binding buffer $(10 \mathrm{mM}$ HEPES/NaOH $\mathrm{pH} 7.4,140 \mathrm{mM} \mathrm{NaCl}$, and $2.5 \mathrm{mM} \mathrm{CaCl}_{2}$ ). Cells were treated with $5 \mu \mathrm{L}$ of Annexin-V FITC (BD, EUA) and $10 \mu \mathrm{L}$ of PI $(50 \mu \mathrm{g} / \mathrm{mL})$ for $15 \mathrm{~min}$ in the dark at room temperature. After incubation, $200 \mu \mathrm{L}$ binding buffer was added and the sample analyzed by flow cytometer. A total of 10.000 events were collected per sample.

\subsubsection{Hemolytic activity}

To evaluate the biocompatibility, we assessed the hemolytic activity of LEG. Briefly, $4 \mathrm{~mL}$ of sheep blood was collected with an anticoagulant (ethylenediaminetetraacetic acid) to obtain erythrocytes. The blood concentration was adjusted to $5 \%$ of erythrocytes in $80 \mu \mathrm{L}$ of PBS and $20 \mu \mathrm{L}$ of LEG was added at concentrations from 800 to $6.25 \mu \mathrm{g} / \mathrm{mL}$. The samples were incubated for $1 \mathrm{~h}$ at $37^{\circ} \mathrm{C}$ and the reaction was interrupted by the addition of $200 \mu \mathrm{L}$ PBS. After centrifugation at $1000 \times g$ for $10 \mathrm{~min}$ at room temperature, the supernatant was analyzed using a spectrophotometer at $550 \mathrm{~nm}$ wavelength to assess the hemolytic activity. Absence of hemolysis (negative control) and 100\% hemolysis (positive control) were determined by replacing the test sample solution with equal volume of PBS and water, respectively.

\subsection{Statistical analysis}

Statistical differences between control and treated cells were evaluated by the analysis of variance (ANOVA) and Bonferroni post hoc test at a significance level of 0.05 using Graph Pad Prism 5.03 (GraphPad Software, La Jolla, CA, USA). The mean half maximal inhibitory concentration $\left(\mathrm{IC}_{50}\right)$ and mean hemolytic concentration $\left(\mathrm{CH}_{50}\right)$ values with confidence limits of $95 \%$ were determined by regression of probits using the software Graph Pad Prism. All values were expressed as means \pm standard error of the mean (SEM) and a value of $p<0.05$ was considered statistically significant. All assays were performed in triplicates in three independent experiments.

\section{Results}

\subsection{Chemical characterization}

UV-Vis spectrophotometry detection was successfully employed for simple and rapid determination of lycopene content in LEG. The spectrophotometric analysis of LEG dissolved in chloroform:ethanol (1:20) revealed three maximum absorbance bands at $\lambda_{\max } 501,471$, and $444 \mathrm{~nm}$, similar to those obtained for the tomato lycopene standard $\left(\lambda_{\max } 504,474\right.$, and $447 \mathrm{~nm}$ ) (Fig. 1). The quantitative analysis

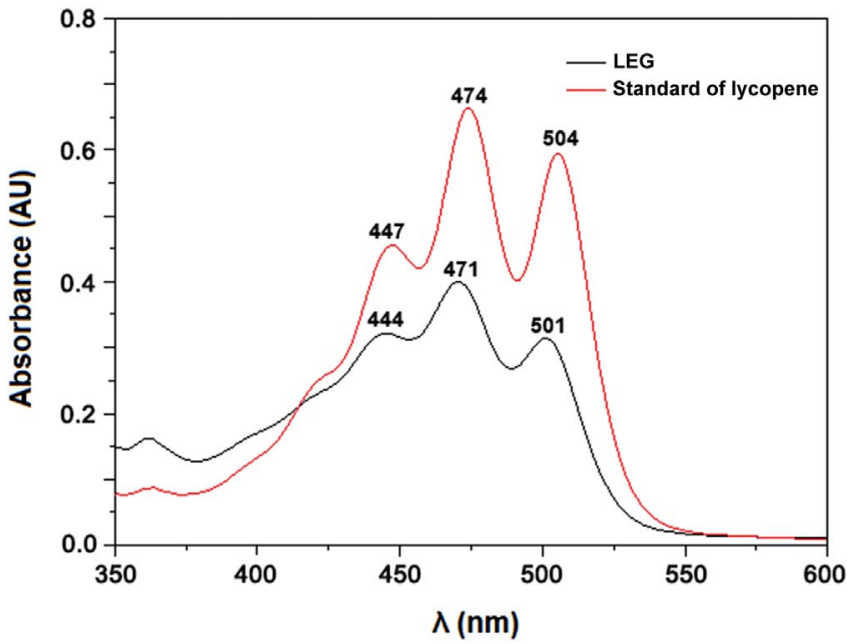

Fig. 1. UV-Vis spectrum (600 to $350 \mathrm{~nm}$ ) of tomato lycopene standard (Sigma-Aldrich) and lycopene-rich extract from red guava (LEG). The external lycopene standard from tomato was dissolved in chloroform:ethanol (1:20) at concentrations from 1 to $10 \mathrm{mg} / \mathrm{L}$. (For interpretation of the references to colour in this figure legend, the reader is referred to the web version of this article.)

performed at $471 \mathrm{~nm}$ wavelength using the calibration curve $\left(y=0.016 x+0.045\left[\begin{array}{rr}r & 2 \\ & 2\end{array} 0.993\right]\right)$ revealed the successful application of the extraction methodology of Amorim et al. (2016) to obtain the lycopene-rich extract ( $20 \%$ of lycopene per extract dry weight).

The identification of lycopene in LEG was performed with high resolution mass spectrometry using an ESI source operating in the positive mode. The results show that lycopene ionizes as a molecular ion $[\mathrm{M}]^{+\bullet}$ of 536.4364. After collision-induced dissociation experiment, it produced four main fragments corresponding to the ions at $m / z$ 467.3658, 444.3788, 375.3034, and 269.2259 (Fig. 2A).

Results from ATR-FTIR analysis of LEG and theoretical all-trans-lycopene, 13-cis-lycopene, and 5-cis-lycopene are shown in Fig. 2B. The regions between 2840 and $1700 \mathrm{~cm}^{-1}$ were omitted for a clearer view of the molecular activity. For theoretical results, infrared (IR) spectra were very similar, as the main difference was related to the positional cis-trans isomerism. In comparison with 5-cis-lycopene, 13-cis-lycopene showed a major discrepancy related to the presence of a peak at $2931 \mathrm{~cm}^{-1}$ and absence of the peak at $1233 \mathrm{~cm}^{-1}$. The general vibrational attributions for both systems were as follows: 955-1000 $\mathrm{cm}^{-1}$ showed out-of-plane $\mathrm{C}-\mathrm{H}$ bending; $1077-1282 \mathrm{~cm}^{-1}$ showed mainly $\mathrm{C}-\mathrm{C}$ stretching and some $\mathrm{C}=\mathrm{C}$ and $\mathrm{C}-\mathrm{H}$ angular modes spread into the entire molecule; $1348 \mathrm{~cm}^{-1}$ showed $\mathrm{CH}_{3}$ rocking; $1420-1425 \mathrm{~cm}^{-1}$ showed $\mathrm{CH}_{3}$ scissoring; $1511-1606 \mathrm{~cm}^{-1}$ indicated $\mathrm{C}=\mathrm{C}$ stretching; the higher wavenumbers $(2870,2903,2931$, and $2968 \mathrm{~cm}^{-1}$ ) presented $\mathrm{C}-\mathrm{H}$ stretching. As other components were also observed in the lycopene-rich extract, the intermolecular interactions were expected to shift the vibrational spectra and produce other vibrational modes. Nevertheless, the bands between 1366 and $1454 \mathrm{~cm}^{-1}$ indicate a reliable fingerprint indicating $\mathrm{C}=\mathrm{C}$ lycopene stretching.

\subsection{LEG was cytotoxic against cancer cells but not normal cell lines}

The cell viability was evaluated by MTT assay following treatment with MCF-7 and NIH-3 T3 cells for 24 and $72 \mathrm{~h}$ and macrophages for $48 \mathrm{~h}$ with LEG. DMSO was used as the vehicle control and showed no effect on cell viability. LEG treatment significantly $(p<0.05)$ affected cell viability of MCF-7 human breast cancer cells in a time and dosedependent manner ( IC $_{50}$ value of 29.85 and $5.964 \mu \mathrm{g} / \mathrm{mL}$ at 24 and $72 \mathrm{~h}$, respectively, Fig. 3). On the contrary, the viability of NIH-3 T3 mice fibroblast cells was unaffected following treatment with LEG at concentrations from 6.25 to $25 \mu \mathrm{g} / \mathrm{mL}$ for $24 \mathrm{~h}$. In comparison with the 
A

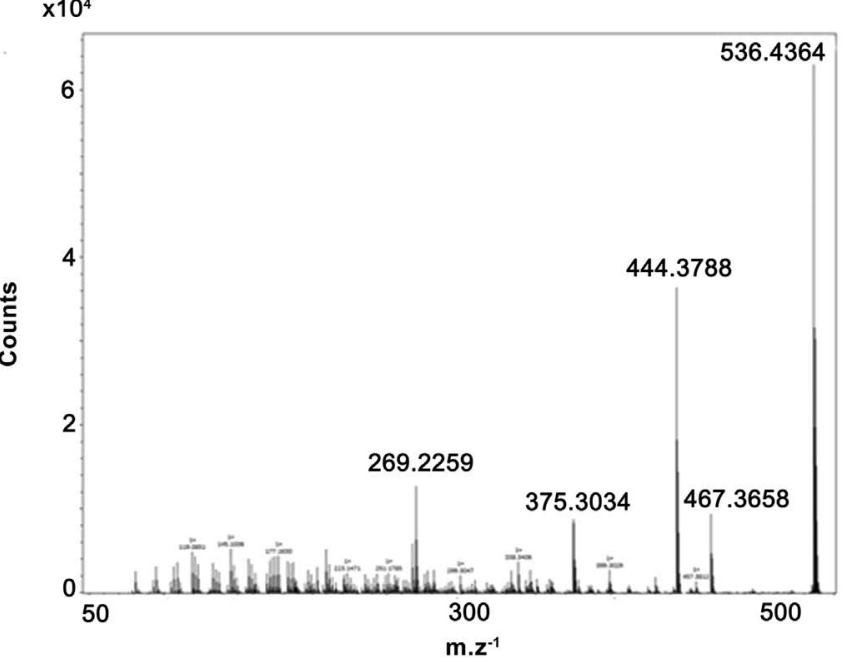

B

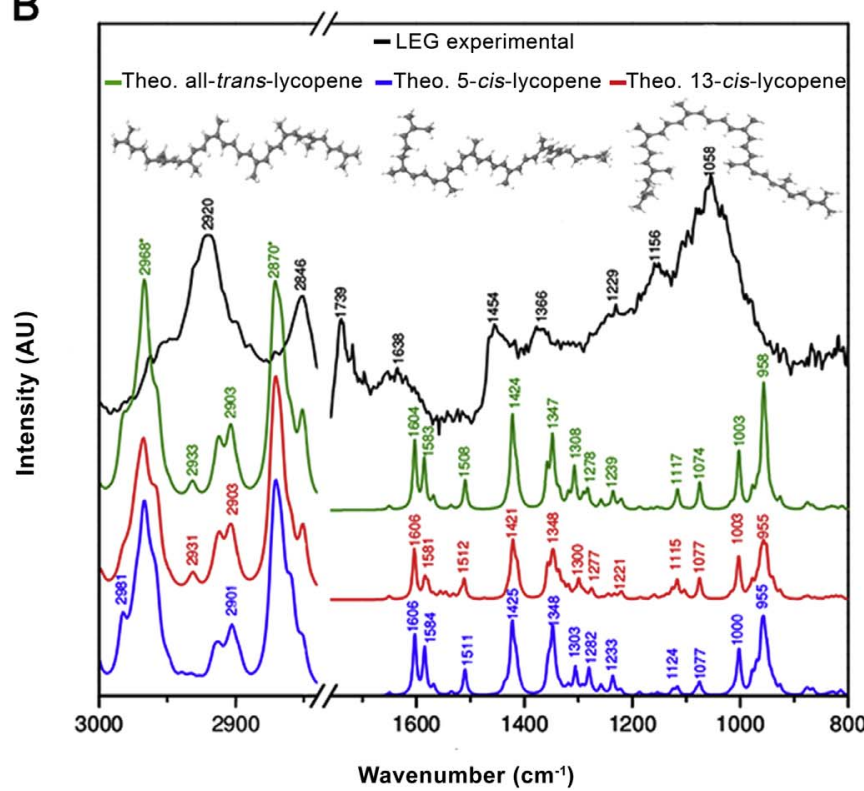

Fig. 2. MS/MS of LEG at the range of $m / z 50$ to 550 (A) and FTIR results for LEG (black line), theoretical IR of all-trans-lycopene (green line), 13-cis-lycopene (red line), and 5-cislycopene (blue line) (B). In $\mathrm{B}$, the numbers above the peaks indicate the respective wavenumber and the inset figures illustrate their respective lycopene isomer forms after DFT optimization. *These theoretical bands have the same wavenumber. (For interpretation of the references to colour in this figure legend, the reader is referred to the web version of this article.)

control cells, NIH-3 T3 cells showed a reduction of $12 \%$ in the cell viability following exposure to LEG at $50 \mu \mathrm{g} / \mathrm{mL}$ concentration for $72 \mathrm{~h}$ (Fig. 4). $\mathrm{IC}_{50}$ value was reported to be 1579 and $911.5 \mu \mathrm{g} / \mathrm{mL}$ at 24 and
$72 \mathrm{~h}$, respectively.

The results of the cytotoxicity of LEG on BALB/c murine macrophages are shown in Fig. 5. A concentration-dependent reduction was observed in the viability of mice peritoneal macrophages, with an $\mathrm{IC}_{50}$ value higher than $800 \mu \mathrm{g} / \mathrm{mL}$. At $800 \mu \mathrm{g} / \mathrm{mL}$ concentration, LEG decreased the viability by around $40 \%$ in NIH-3 T3 cells but $90 \%$ in MCF7 cells. These results indicate that LEG displays higher selectivity toward MCF-7 cells than NIH-3 T3 cells or BALB/c murine peritoneal macrophages. $\mathrm{IC}_{50}$ values are summarized in Table 1.

\subsection{LEG had no effect on the cell membrane}

Analysis of the effect of LEG on the membrane integrity of MCF-7 cells revealed that the treatment with LEG at 400 and $800 \mu \mathrm{g} / \mathrm{mL}$ concentrations failed to exert any significant damage (disruption) to the cell membrane at 24 and $72 \mathrm{~h}$ as compared with the control group (Fig. 6).

\subsection{LEG affected MCF-7 proliferation}

As shown in Fig. 7, no significant effect was observed on the number of MCF-7 human breast cancer cells following exposure to LEG at $400 \mu \mathrm{g} / \mathrm{mL}\left(94 \pm 11 \times 10^{4}\right.$ cells $\left./ \mathrm{mL}\right)$ and $800 \mu \mathrm{g} / \mathrm{mL}\left(71 \pm 5 \times 10^{4}\right.$ cells) concentrations for $24 \mathrm{~h}$ as compared with the control group (97 $\pm 3 \times 10^{4}$ cells). On the other hand, a significant reduction $(p<0.05)$ was observed in the proliferation of MCF-7 cells following treatment with LEG for $72 \mathrm{~h}$ at $400 \mu \mathrm{g} / \mathrm{mL}\left(98 \pm 14 \times 10^{4}\right.$ cells $)$ and $800 \mu \mathrm{g} / \mathrm{mL}$ ( $35 \pm 9 \times 10^{4}$ cells) concentrations as compared with the control group (216 $\pm 31 \times 10^{4}$ cells) group.

\subsection{LEG increased DNA fragmentation and induced cell cycle arrest in MCF-7 cells}

A significant $(p<0.05)$ increase in DNA fragmentation was observed in MCF-7 cells treated with LEG at 400 and $800 \mu \mathrm{g} / \mathrm{mL}$ concentrations for 24 and $72 \mathrm{~h}$ (Fig. 8). In addition, LEG significantly affected the cell cycle phases of MCF-7 cells at both doses. After $72 \mathrm{~h}$ of exposure at 400 and $800 \mu \mathrm{g} / \mathrm{mL}$ concentrations, the cells were arrested in G1 phase (Fig. 9B). Furthermore, a significant increase was observed in the number of cells in the $\mathrm{G} 2 / \mathrm{M}$ phase at $400 \mu \mathrm{g} / \mathrm{mL} \mathrm{LEG}$, while $800 \mu \mathrm{g} / \mathrm{mL}$ LEG affected the $S$ phase (Fig. 9B).

\subsection{LEG induced alterations in the mitochondrial membrane potential of MCF-7 cells}

The exposure of MCF-7 cells to LEG for 24 and $72 \mathrm{~h}$ induced significant $(p<0.05)$ modifications in the mitochondrial membrane potential. Flow cytometry data showed a decline in the population of cells stained positive for rhodamine 123 following treatment with 400 and $800 \mu \mathrm{g} / \mathrm{mL}$ LEG at 24 and $72 \mathrm{~h}$, demonstrating the depolarization of mitochondrial membrane (Fig. 10A and B). The population of cells with altered membrane potential was about $62 \%$ and $63 \%$ following treatment with $400 \mu \mathrm{g} / \mathrm{mL}$ LEG for $24 \mathrm{~h}$ and $800 \mu \mathrm{g} / \mathrm{mL}$ LEG for $72 \mathrm{~h}$,
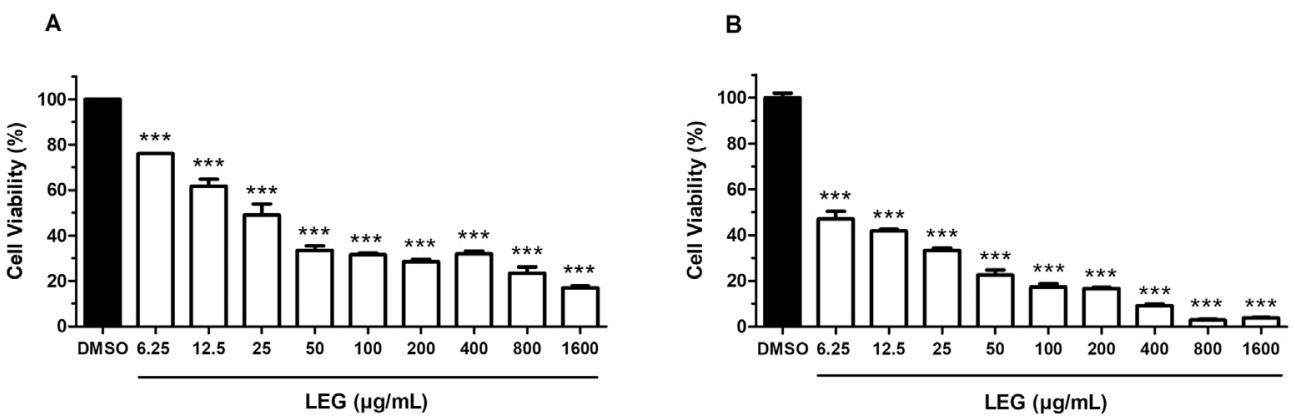

Fig. 3. Effects of LEG on the viability of human breast cancer (MCF-7) cells after exposure for $24 \mathrm{~h}$ (A) and $72 \mathrm{~h}$ (B). The assay was carried out using MTT method and the absorbance was monitored at $595 \mathrm{~nm}$ wavelength. The values are expressed as mean \pm SEM. $* * * p<0.0001$ versus DMSO control group. 

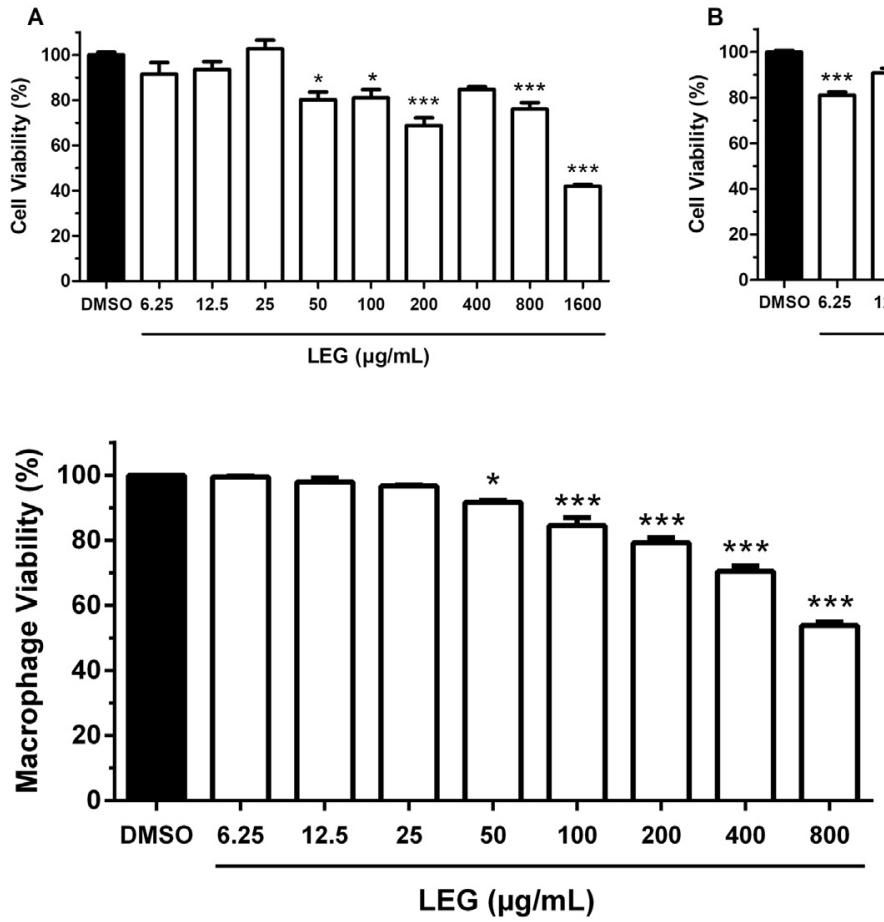

Fig. 5. Cytotoxicity of LEG on peritoneal macrophages from BALB/c mice. The assay was carried out using MTT method and the absorbance was monitored at $550 \mathrm{~nm}$ wavelength. The values are expressed as mean \pm SEM. ${ }^{*} p<0.05$ versus DMSO control group; *** $p<0.0001$ versus DMSO control group.

Table 1

Summary of the half maximal inhibitory concentration $\left(\mathrm{IC}_{50}\right)$ value for cancer and normal cells treated with LEG, as evaluated using MTT method.

\begin{tabular}{llll}
\hline \multirow{2}{*}{ Cell line } & \multicolumn{2}{l}{$\mathrm{IC}_{50}(\mu \mathrm{g} / \mathrm{mL})$} & \\
\cline { 2 - 4 } & $24 \mathrm{~h}$ & $48 \mathrm{~h}$ & $72 \mathrm{~h}$ \\
\hline Human breast adenocarcinoma cells (MCF-7) & 29.85 & - & 5.964 \\
Murine fibroblast cells (NIH-3 T3) & 1579 & - & 911.5 \\
BALB/c murine peritoneal macrophages & - & $>800$ & - \\
\hline
\end{tabular}

respectively (Fig. 10C).

\subsection{LEG induced morphologic alterations in MCF-7 cells}

Flow cytometry analysis of MCF-7 cells showed that treatment of cells with LEG for 24 and $72 \mathrm{~h}$ resulted in a significant $(p<0.05)$ reduction in the cell size as compared with the DMSO control group, indicative of cell death (Fig. 11A). On the other hand, a small increase
Fig. 4. Effects of LEG on the viability of normal mouse fibroblast (NIH-3 T3) cells following exposure for $24 \mathrm{~h} \mathrm{(A)}$ and $72 \mathrm{~h}$ (B). The assay was carried out using MTT method and the absorbance was measured at $595 \mathrm{~nm}$ wavelength. The values are expressed as mean \pm SEM. * $p<0.05$ versus DMSO control group; *** $p<0.0001$ versus DMSO control group.
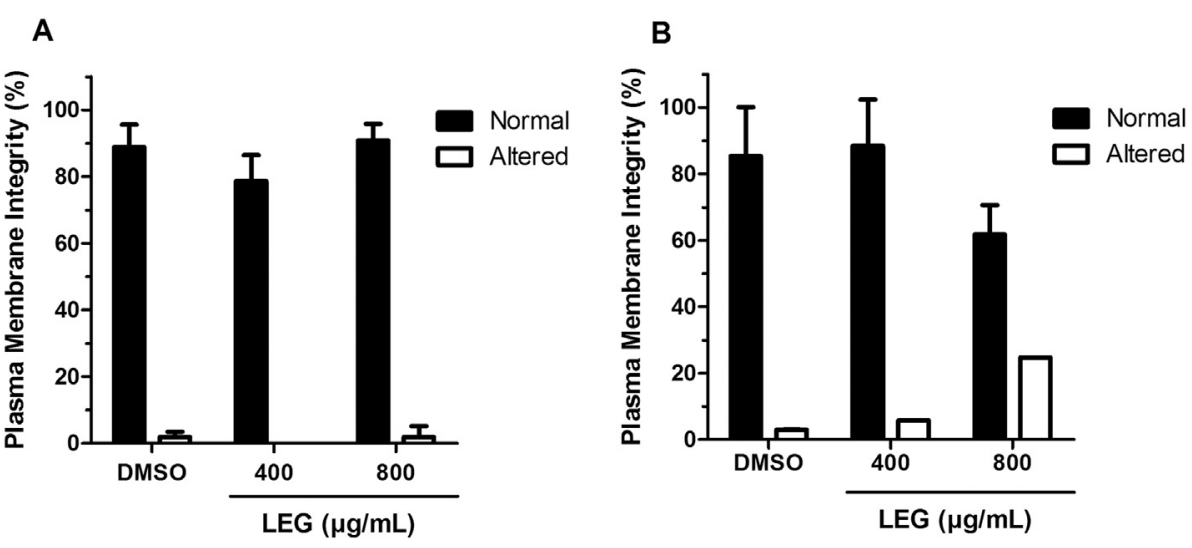

Fig. 6. Effects of LEG on the membrane integrity of MCF-7 cells following treatment for $24 \mathrm{~h}$ (A) and $72 \mathrm{~h}$ (B). The assay was performed with the trypan blue staining method and the cells were counted using a Neubauer chamber. Cells were classified into altered (disrupted membrane, stained) or normal cells (undamaged membrane). The values are expressed as mean \pm SEM. No significant difference was observed as compared with DMSO control group. (For interpretation of the references to colour in this figure legend, the reader is referred to the web version of this article.)

Fig. 7. Effects of LEG on MCF-7 cell proliferation following exposure for 24 and $72 \mathrm{~h}$. The in cellular granularity was observed at $24 \mathrm{~h}$ (Fig. 11B). In comparison with the control group, cells treated with LEG for 24 and $72 \mathrm{~h}$ at 400 and $800 \mu \mathrm{g} / \mathrm{mL}$ concentrations showed morphological changes suggestive of cell shrinkage (Fig. 12).

\subsection{LEG failed to induce necrosis or apoptosis in MCF-7 cells}

After treatment with LEG for 24 and $72 \mathrm{~h}$, no significant changes in Annexin- $V$ FITC staining were observed for MCF-7 cells, as analyzed by flow cytometry. On the contrary, a significant increase in PI fluorescence intensity $(p<0.0001)$ was observed at both concentrations cytometry also autofluorescence property of LEG (Fig. 15C and F) and hence, had no relation with the plasma membrane disruption. 


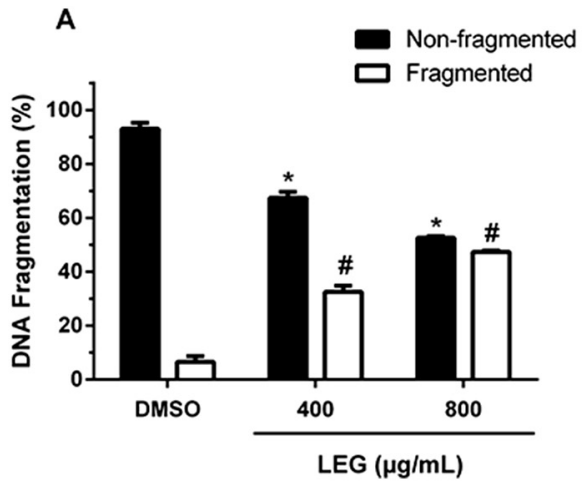

\subsection{LEG showed no hemolytic activity}

The treatment of erythrocytes with LEG at $800 \mu \mathrm{g} / \mathrm{mL}$ concentration resulted in only $5 \%$ reduction in the cell viability (Fig. 17). Therefore, $\mathrm{CH}_{50}$ value was not determined, indicative of the absence of cytotoxicity of LEG in the cell model used.

\section{Discussion}

The study on the role of bioactive substances, especially from natural sources, against breast cancer has vital importance, owing to the high incidence of breast cancer and difficulty involved in its treatment. In this direction, lycopene is known as a potential anticancer agent, which can be used as an alternative to currently available therapies for breast cancer treatment. The lycopene content of red guava is higher than that from other known sources such as tomato, watermelon, mango, and papaya (Mangels, Holden, Beecher, Forman, \& Lanza, 1993; Oliveira et al., 2010; Vargas-Murga et al., 2016). Furthermore, red guava fruit is popularly used as food and medicine, but there are very few pharmacological studies demonstrating its biological activity against cancer. Thus, we evaluated LEG for its cytotoxic effects on normal and cancer cell lines and studied its mechanism of action.

Chemical information about LEG was obtained using sensitive techniques, which allowed the determination and identification of the lycopene content and key components in the extract, demonstrating the successful application of the extraction process. The absorption peaks obtained with UV-Vis spectrophotometry for LEG corresponded with the previously established data for lycopene from other sources. The analysis of the methanolic extract of lycopene from tomato performed using UV-Vis showed peaks at wavelengths of 447.2, 473.2, and $504.2 \mathrm{~nm}$ and these values corresponded to the profile of pure lycopene (Aghel, Ramezani, \& Amirfakhrian, 2007). In addition, Honda et al. (2015) reported that the maximum wavelengths for all-trans-lycopene and 5-cis-lycopene dissolved in hexane were 444, 470, and $501 \mathrm{~nm}$-values close to those previously reported. Statistically significant differences $(p<0.05)$ were detected between maximum wavelengths for lycopene isomers in samples of tomato products; all-trans- lycopene presented $\lambda_{\text {máx }}$ of 445, 472, and $502 \mathrm{~nm}$, while 5-cis-lycopene presented $\lambda_{\text {máx }}$ of 446,471 , and $502 \mathrm{~nm}$ using ethyl acetate as a solvent (Stinco et al., 2013).

In mass spectrum obtained after collision-induced dissociation of the molecular ion $m / z 536.4364$, the fragments characteristic for lycopene: $m / z$ 467.3658, 444.3788, and 375.3034 were found. The spectrum of lycopene can be distinguished from that of $\beta$-carotene by the presence of the fragment $m / z 467$ (Arathi et al., 2015). Furthermore, some studies indicate also the presence of the fragment $\mathrm{m} / \mathrm{z} 521$ as the diagnostic ion for cis-lycopene (Arathi et al., 2015; Dong et al., 2010). Since in our MS/MS spectrum this fragment was absent, our results suggest that LEG contains mostly all-trans-lycopene.

In comparison with the theoretical DFT calculations, the vibrational FTIR of the sample indicates some fingerprints highlighting $\mathrm{C}=\mathrm{C}$ stretching in the region of $1366-1454 \mathrm{~cm}^{-1}$. On the other hand, the theoretical method was unable to capture the difference between the isomers but infers that both forms are, in principle, present in LEG. The 11 conjugated double bonds allow lycopene to assume around 72 structurally favorable cis-isomers; its chemical stability may be affected by three main factors: heat, light, and oxygen. In addition, some solvents may cause its isomerization from all-trans to mono or poly-cis form (Srivastava \& Srivastava, 2015). Although our results indicate that LEG mainly comprises all-trans-lycopene, cis-isomers may be present at lower concentrations.

Previous studies have highlighted the vibrational properties of lycopene. Baranska, Schütze, and Schulz (2006) showed that FTIR may be a fast and nondestructive characterization method for lycopene quantification. This method was subsequently improved through its combination with ATR-IR (De Nardo, Shiroma-Kian, Halim, Francis, \& Rodriguez-Saona, 2009), multivariate statistical analysis (Giusti, Atnip, Sweeney, \& Rodriguez-Saona, 2011), high-performance liquid chromatography (Kim et al., 2015), or in-situ Raman (Trebolazabala, Maguregui, Morillas, de Diego, \& Madariaga, 2017).

The results of MTT assay showed that LEG was effective as an anticancer agent at all tested concentrations and both time points. The anticancer activity was assessed on MCF-7 cells, a human breast adenocarcinoma cell line isolated from a 69 -year-old Caucasian woman in

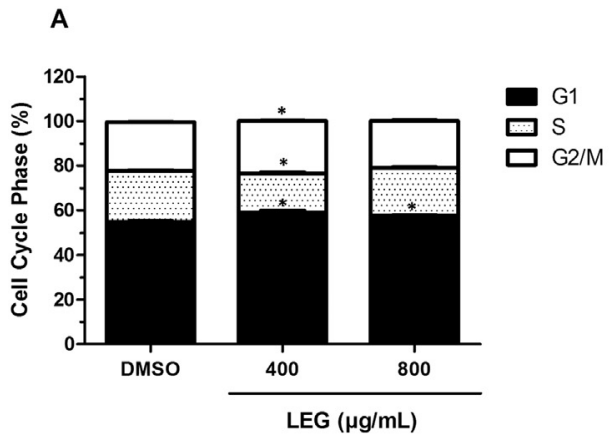

\section{B}

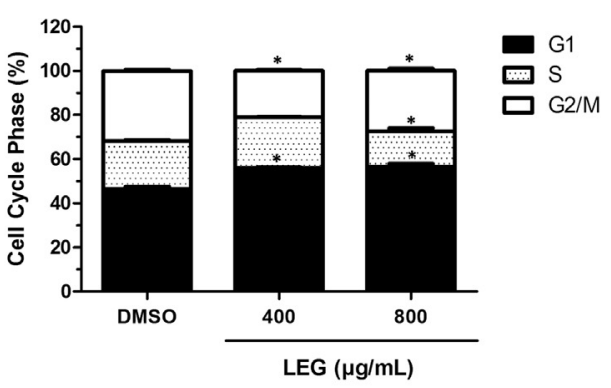

Fig. 9. Effects of LEG on MCF-7 cell cycle following exposure for $24 \mathrm{~h} \mathrm{(A)}$ and $72 \mathrm{~h}$ (B). The cells were incubated with propidium iodide for $30 \mathrm{~min}$ at room temperature and the cell cycle was analyzed by flow cytometry (10.000 events/sample). The values are represented as mean \pm SEM. * $p<0.05$ versus DMSO control group. 
A

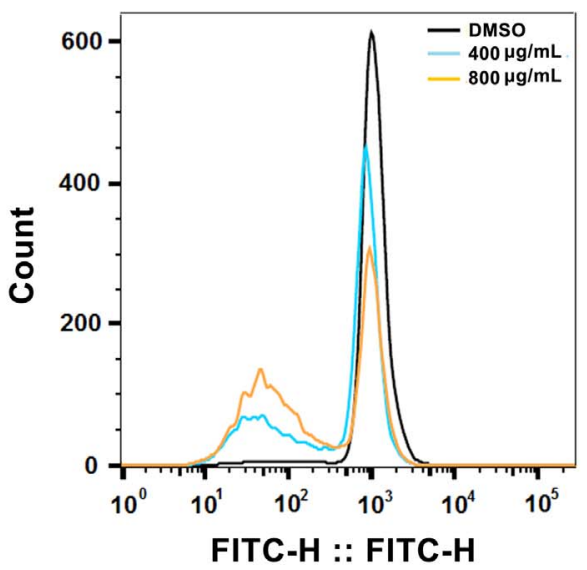

B

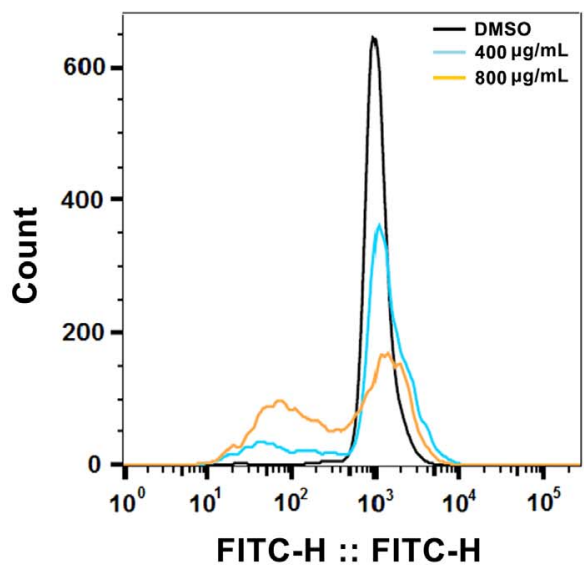

Fig. 10. Effects of LEG on the mitochondrial membrane potential of MCF-7 cells following exposure for 24 (A) and 72 (B) $\mathrm{h}$, as evaluated by flow cytometry. (C) A representative graph of the percentage of cells with altered membrane potential. The values are expressed as mean \pm SEM. $* p<0.05$ versus DMSO control group; $* * *$ $p<0.0001$ versus DMSO control group.

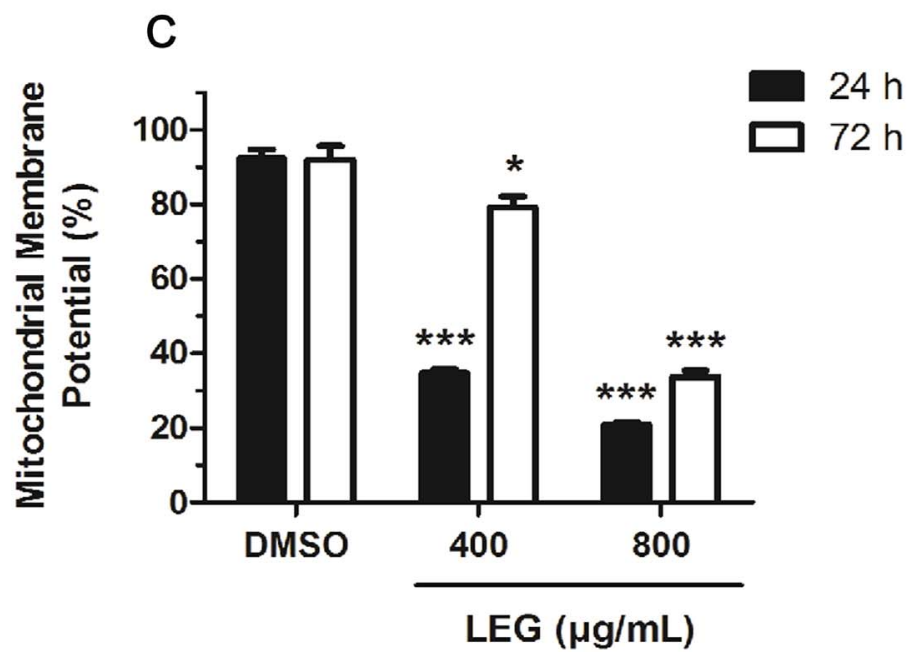

1970 (Yalvac et al., 2009). Long-term exposure (72 h) of MCF-7 cells to LEG resulted in lower IC $_{50}$ values as compared with normal cells such NIH-3 T3 and BALB/c peritoneal macrophages. The preferable selectivity of LEG toward cancer cells suggests its potential application as an anticancer agent.

Some reports indicate the direct relationship between lycopene supplementation or consumption of foods containing high content of lycopene and cancer reduction. Mariani et al. (2014) supplemented thirty-two patients with high-grade prostatic intraepithelial neoplasia (HGPIN) with a lycopene-enriched diet (20-25 mg/day of lycopene through $30 \mathrm{~g} /$ day of triple concentrated tomato paste) for 6 months and found that patients with prostate cancer showed lower prostate concentration of lycopene as compared to those with HGPIN, supporting the beneficial role of lycopene accumulation against the development of prostate cancer.

Numerous studies investigating the effects of lycopene on cancer cells have been recently published. Together, these studies highlight the following findings: reduction in MCF-7 cell viability; cell proliferation inhibition and cell cycle arrest; modulation of intracellular communication of the gap junction; induction of apoptosis; modulation of cell cycle proteins; increase in BRCA1 and BRCA2 mRNA (onco-suppressor genes in breast cancer); alterations in the gene expression profile of various other molecular pathways such as apoptosis (p53 and Bax), cell communication, MAPK, cell cycle, xenobiotic metabolism, and fatty acid biosynthesis (Chalabi et al., 2006; Chalabi, Le Corre, Maurizis, Bignon, \& Bernard-Gallon, 2004; Chalabi, Satih, Delort, Bignon, \& Bernard-Gallon, 2007; King-Batoon, Leszczynska, \& Klein, 2008; Levy et al., 1995; Peng et al., 2017; Reddy, Alexander-Lindo, \& Nair, 2005;
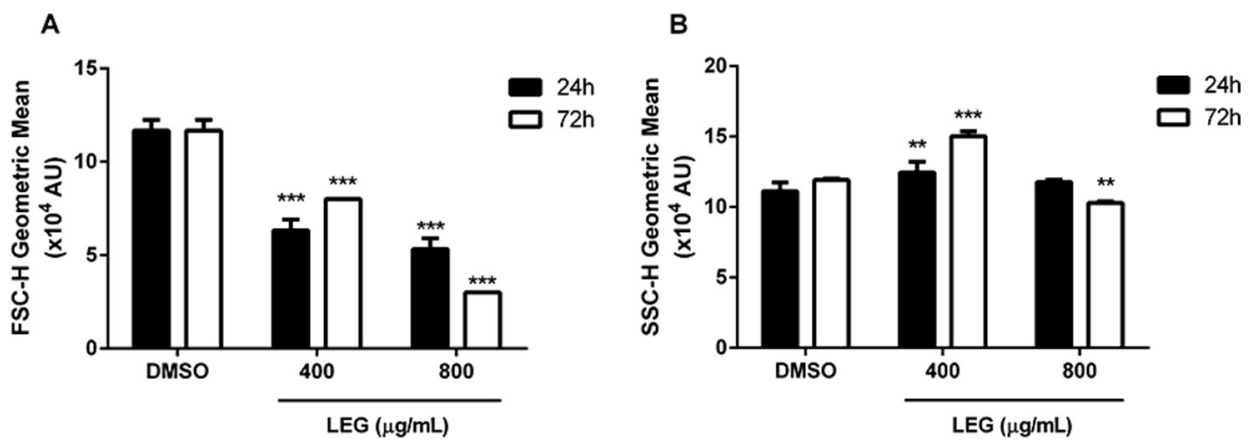

Fig. 11. Effects of LEG on FSC-H = size (A) and SSC$\mathrm{H}=$ granularity (B) of MCF-7 cells following treatment at 400 and $800 \mu \mathrm{g} / \mathrm{mL}$ concentrations for 24 and $72 \mathrm{~h}$. The cells were analyzed by flow cytometry (10.000 events/sample). ${ }^{* *} p<0.001$ versus DMSO control group; *** $p<0.0001$ versus DMSO control group. 
A
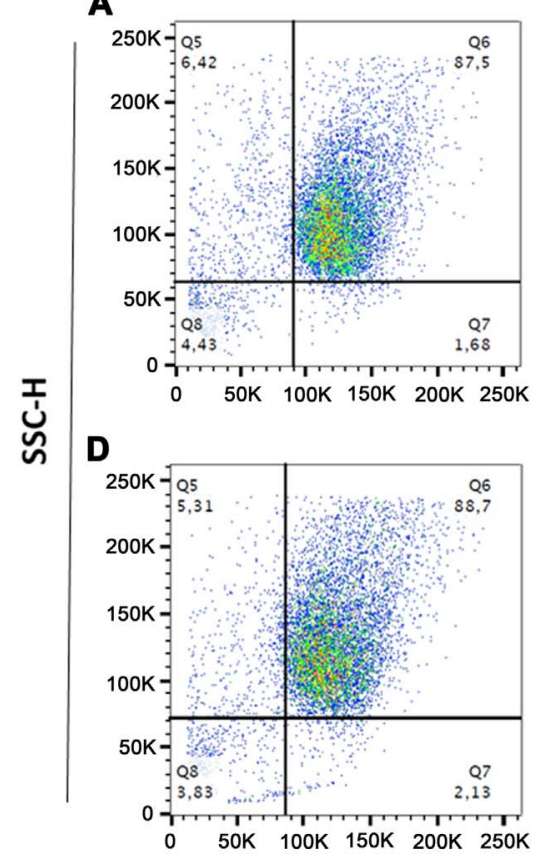

B

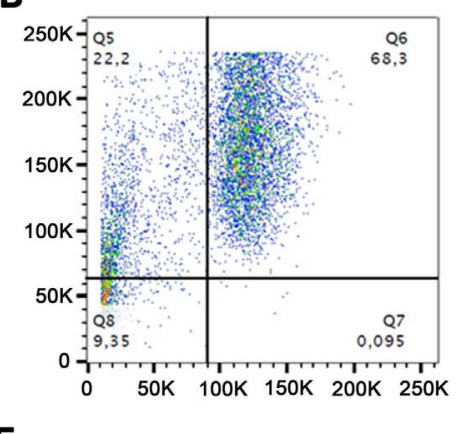

E

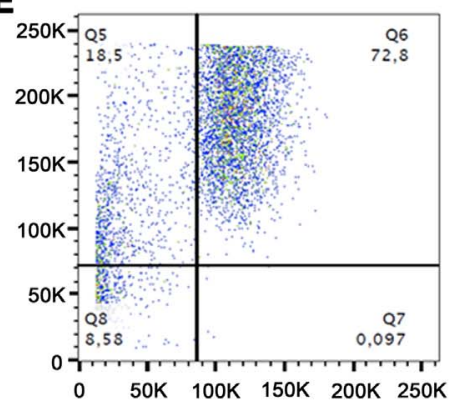

C

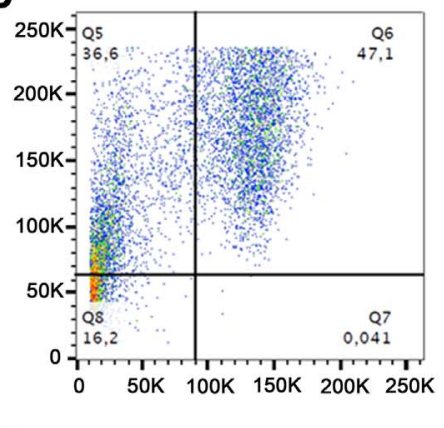

$\mathbf{F}$

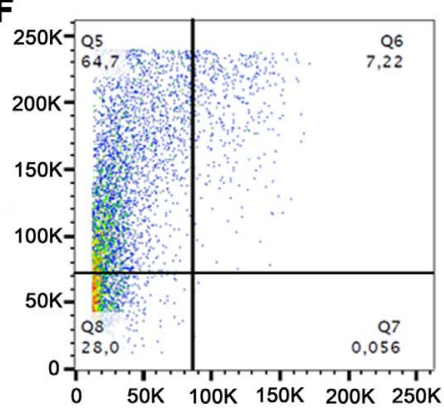

FSC-H

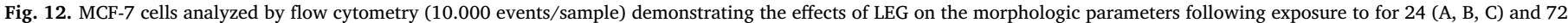
(D, E, F) h at $400 \mu \mathrm{g} / \mathrm{mL}$ (B, E) and $800 \mu \mathrm{g} / \mathrm{mL}$ (C, F) as compared with the DMSO control group (A, D). FSC-H = size; SSC-H = granularity.
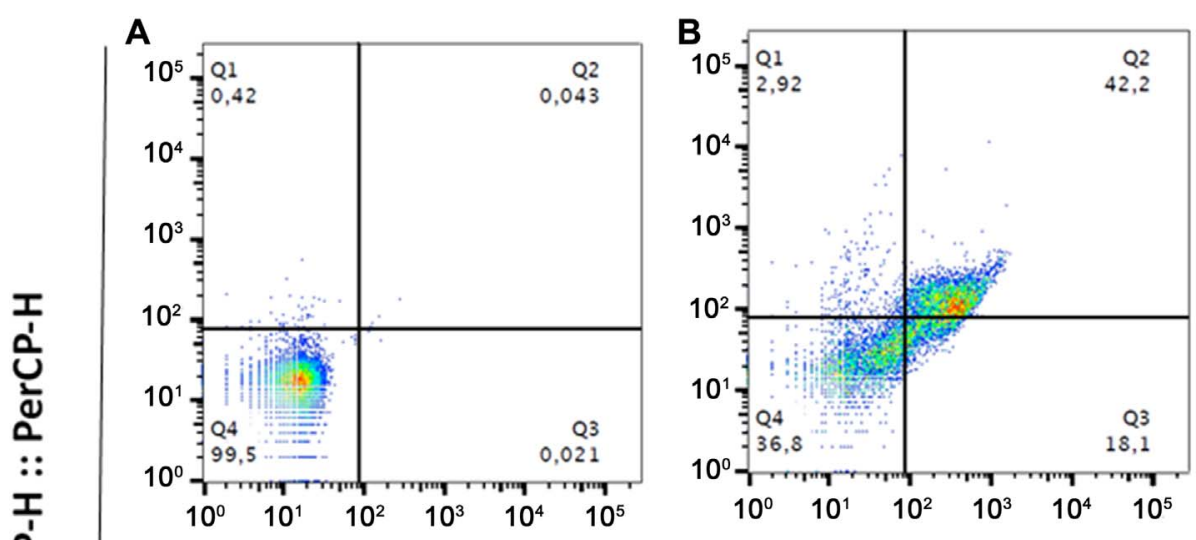

Fig. 13. Analysis of MCF-7 cells by flow cytometry (10.000 events/sample) to evaluate the mechanism underlying the effects of LEG on cell death using Annexin- $V$ FITC/propidium iodide staining after treatment of cells for $24 \mathrm{~h}$ at $400 \mu \mathrm{g} / \mathrm{mL}$ (C) and $800 \mu \mathrm{g} / \mathrm{mL}$ (D) as compared with DMSO control (A) and $\mathrm{H}_{2} \mathrm{O}_{2}$ control (B).
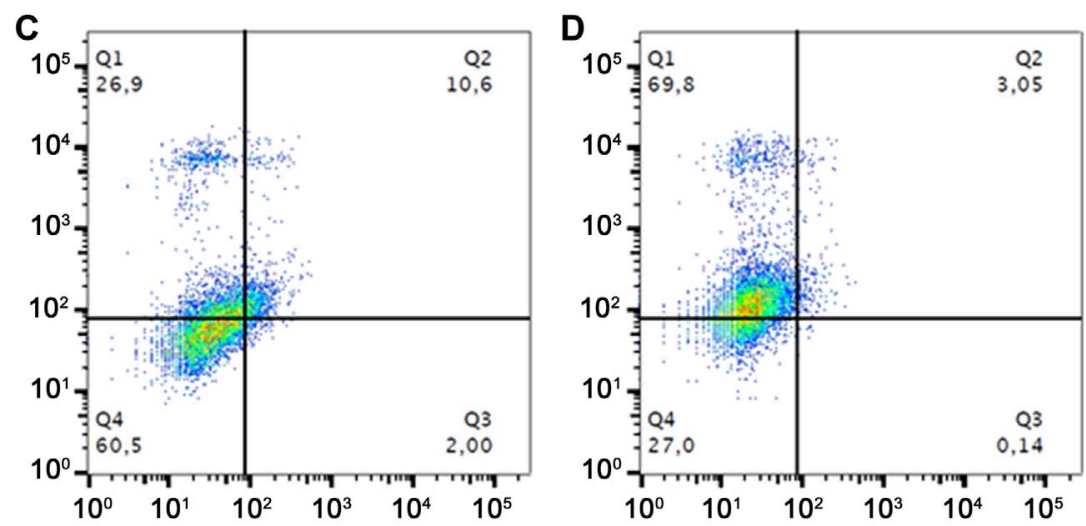

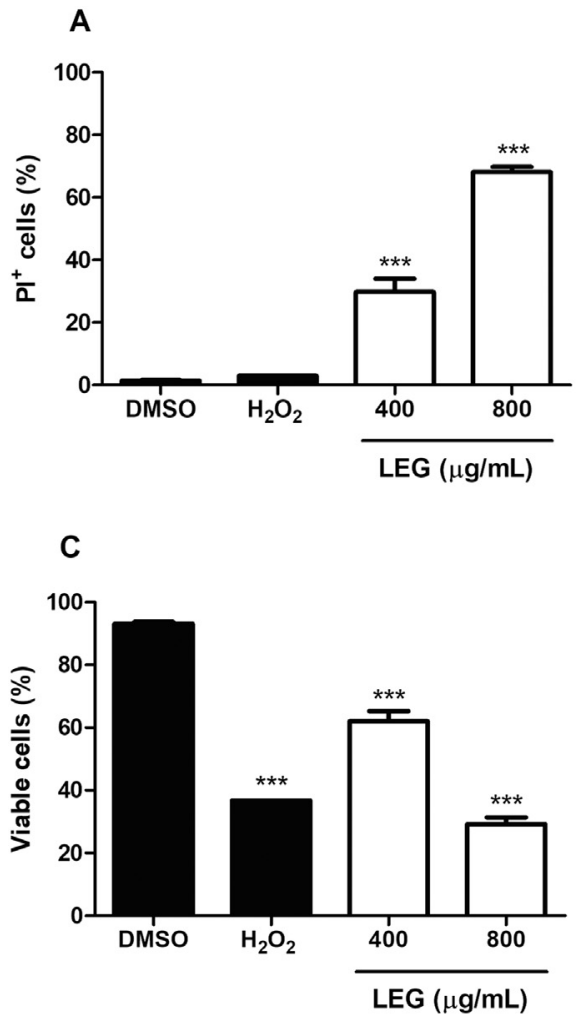

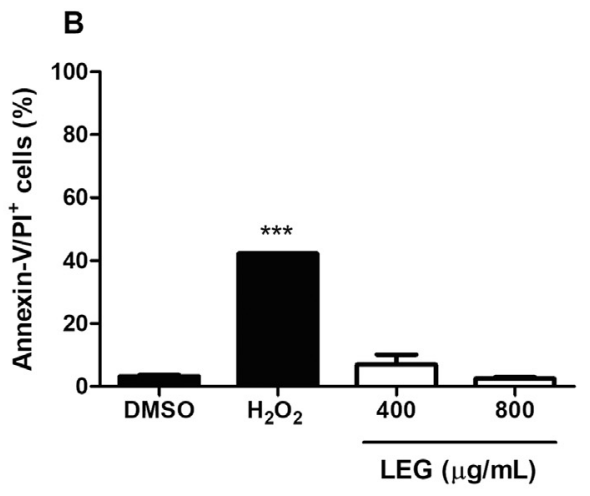

Fig. 14. Evaluation of the mechanism underlying cell death mediated by LEG in MCF-7 cells following treatment for $24 \mathrm{~h}$ at 400 and $800 \mu \mathrm{g} / \mathrm{mL}$ concentrations. Cells stained with PI (A), Annexin-V FITC/PI (B), viable cells (C), and Annexin-V FITC (D). Cells were analyzed by flow cytometry (10.000 events/sample). ** $p<0.001$ versus DMSO control group; *** $p<0.0001$ versus DMSO control group.
Takeshima et al., 2014; Uppala, Dissmore, Lau, Andacht, \& Rajaram, 2013). Gloria et al. (2014) described that lycopene (10\%) purchased from Sigma Chemical Company (St. Louis, MO, USA) induced a significant decrease in the number of viable breast cancer cells and caused cell cycle arrest after $96 \mathrm{~h}$, as evident with an increase in apoptosis. These data are similar to the results obtained in this study,

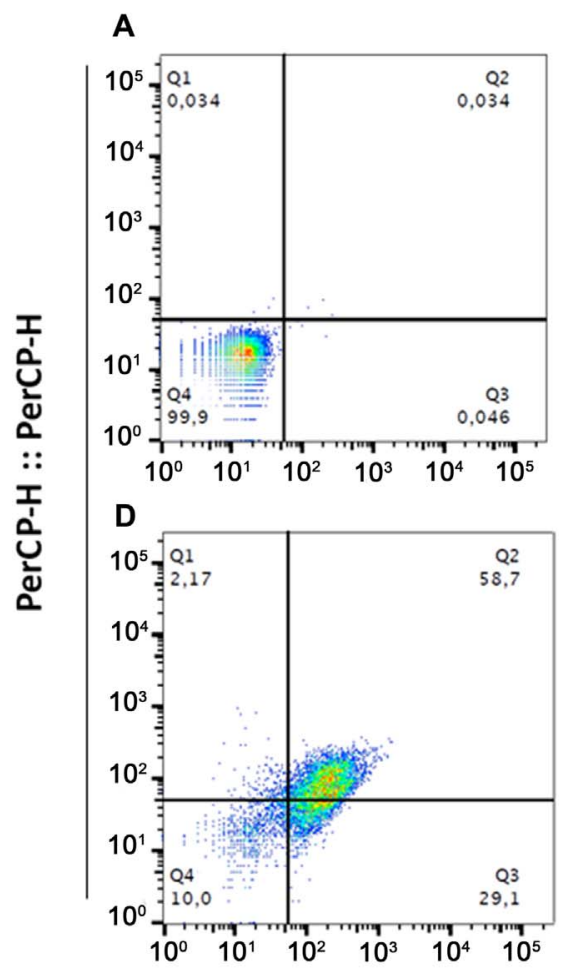

B

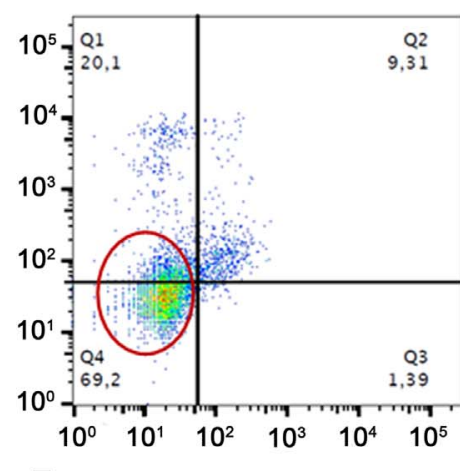

E

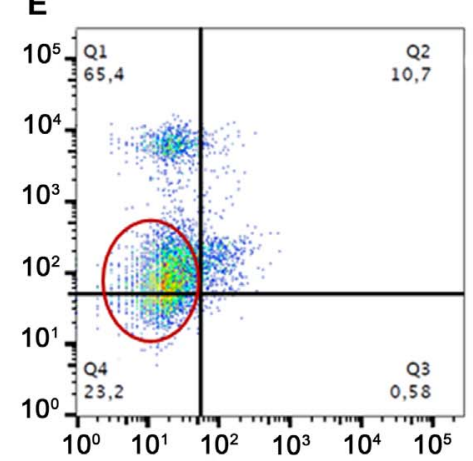

C

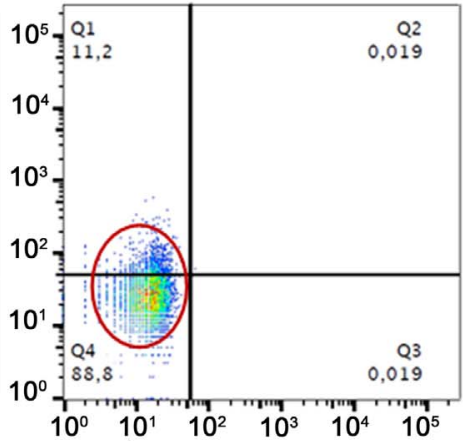

$\mathbf{F}$

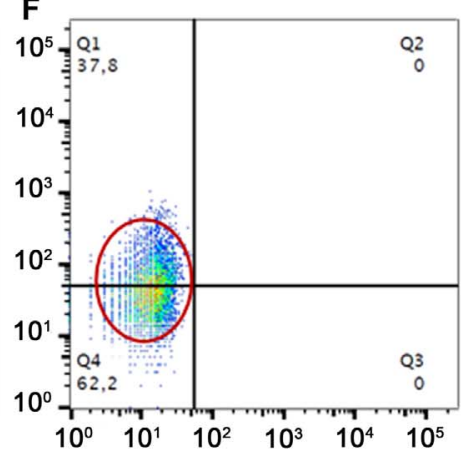

FITC-H :: FITC-H

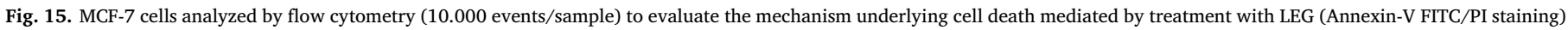

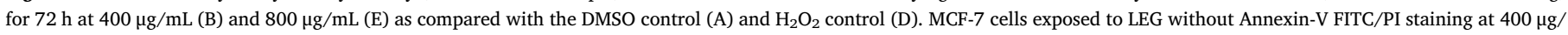
$\mathrm{mL}(\mathrm{C})$ and $800 \mu \mathrm{g} / \mathrm{mL}(\mathrm{F})$. 

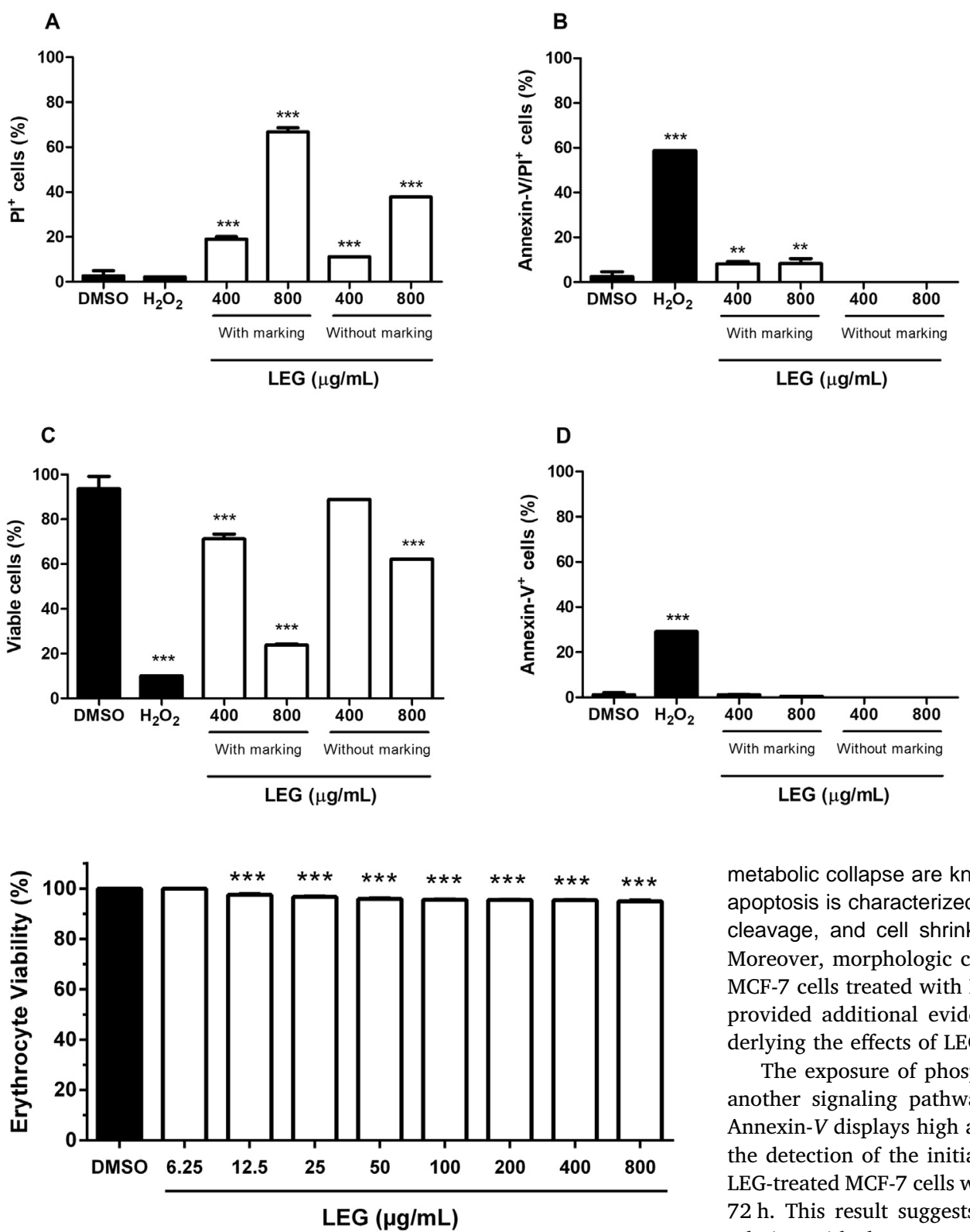

Fig. 17. Cytotoxicity of LEG against sheep blood erythrocytes. The values are expressed as mean \pm SEM. ${ }^{* * *} p<0.0001$ versus DMSO control group.

wherein LEG decreased the number of viable MCF-7 cells and induced cell cycle arrest and DNA fragmentation.

The cell cycle arrest in G1 phase in conjunction with the reduction in the proliferation of LEG-treated cells indicate the cytostatic effects of LEG on human breast adenocarcinoma cell line. During G1 phase of the cell cycle, the cell can continue the cycle and divide or remain in a state of non-division. The transition from G1 to $\mathrm{S}$ phase is crucial for the control of eukaryotic cell proliferation and any dysregulation at this point may promote oncogenesis (Bertoli, Skotheim, \& De Bruin, 2013). Thus, the cell cycle arrest in G1 phase in MCF-7 cells after $72 \mathrm{~h}$ of treatment with LEG suggests the ability of this extract to prevent cancerous cell division and proliferation.

DNA fragmentation observed in LEG-treated human breast adenocarcinoma cells is an important hallmark of cell death by apoptosis. LEG caused no significant damage to the plasma membrane of MCF-7 cells but induced significant modifications in the mitochondrial membrane potential. Mitochondrial membrane potential plays an important role in ATP formation as well as cell survival and is associated with apoptosis (Joanitti et al., 2010). Furthermore, plasma membrane disruption and

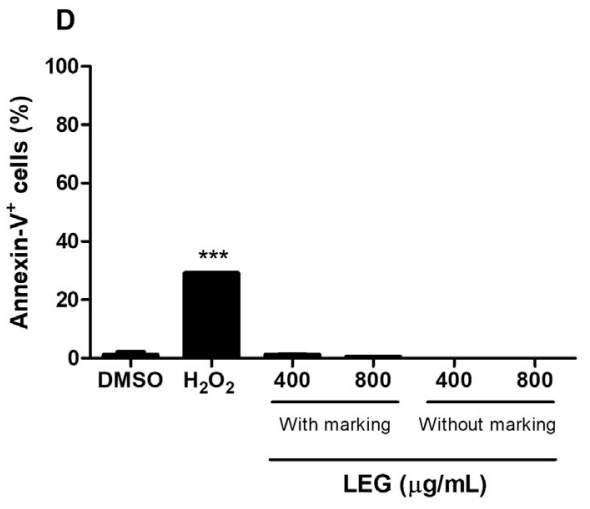
toxic to healthy cells.
Fig. 16. The mechanism underlying cell death mediated by LEG following exposure of MCF-7 cells for $72 \mathrm{~h}$ at 400 and $800 \mu \mathrm{g} / \mathrm{mL}$ concentrations. Cells stained with PI (A), Annexin-V FITC/PI (B), viable cells (C), and Annexin-V FITC (D). Cells were analyzed by flow cytometry (10.000 events/sample). ** $p<0.001$ versus DMSO control group; $* * *$ $p<0.0001$ versus DMSO control group.

metabolic collapse are known as the typical features of necrosis, while apoptosis is characterized by chromatin condensation, systematic DNA cleavage, and cell shrinkage (Dive et al., 1992; Yang et al., 2017). Moreover, morphologic changes related to the granularity and size of MCF-7 cells treated with LEG indicated a pattern of cell shrinkage and provided additional evidences for understanding the mechanism underlying the effects of LEG on this cell line.

The exposure of phosphatidylserine on the inner membrane is yet another signaling pathway regulating apoptosis (Jain et al., 2013). Annexin- $V$ displays high affinity for phosphatidylserine and is used for the detection of the initial phase of apoptosis. However, only $10 \%$ of LEG-treated MCF-7 cells were positive for Annexin-V FITC staining after $72 \mathrm{~h}$. This result suggests that the mechanism of cells death had no relation with the exposure of phosphatidylserine, which occurs in the traditional apoptosis pathway. Moreover, no conclusive results were obtained from the investigation of the necrosis pathway by flow cytometry, as LEG demonstrated red fluorescence at a wavelength similar to that of PI, a marker used to detect binding of the plasma membrane to the nucleic acid. However, no harmful effects on the plasma membrane were detected by trypan blue assay. These results suggest that necrosis pathway had no role in MCF-7 cells death, but LEG exhibits anticancer activity by mediating cell death via an apoptotic-like pathway.

A noteworthy observation of this study is the low cytotoxicity of LEG against NIH-3 T3 normal mice fibroblast cells and BALB/c murine peritoneal macrophages, as demonstrated by MTT assay. The low cytotoxicity of LEG was also confirmed by the evaluation of the hemolytic activity in sheep erythrocytes. Chisté, Freitas, Mercadante, and Fernandes (2014) evaluated the potential of carotenoids to inhibit hemolysis of human erythrocytes mediated by peroxyl radicals and found that lycopene was the most efficient carotenoid to prevent hemolysis $\left(\mathrm{IC}_{50}=0.24 \pm 0.05 \mu \mathrm{M}\right)$. These results demonstrate that LEG is non- 


\section{Conclusions}

The extract of lycopene obtained from red guava contained $20 \%$ lycopene mostly in the form of all-trans-lycopene isomers. LEG was able to decrease the viability of human breast adenocarcinoma cells and showed no significantly effects on normal cells such as NIH-3 T3 fibroblasts, BALB/c macrophages, and erythrocytes. The partial mechanism of action involves DNA fragmentation, cell cycle arrest, depolarization of mitochondrial membrane, and changes in morphology features, thereby inducing cytostatic and cytotoxic effects distinctive of an apoptotic-like pathway. Our results suggest the potential applications of lycopene from red guava in the development of economically viable and sustainable anticancer product.

\section{Acknowledgments}

The authors acknowledge the computational time provided by CENAPAD/SP on the project proj697. Alexandra Plácido is gratefully to FCT by her grant SFRH/BD/97995/2013, financed by POPH-QREN-Tipologia 4.1-Formação Avançada, subsidized by Fundo Social Europeu and Ministério da Ciência, Tecnologia e Ensino Superior. The work at REQUIMTE/LAQV received financial support from the European Union (FEDER funds through COMPETE) and National Funds (FCT) through project UID/QUI/50006/2013. Adriany das G. N. Amorim is grateful to CAPES by for the doctoral fellowship process no. 99999.004236/2014-09 in Federal University of Piauí (UFPI). Eder A. Barbosa is grateful to PNPD/CAPES for its post-doctoral fellowship.

\section{References}

Aghel, N., Ramezani, Z., \& Amirfakhrian, S. (2007). Isolation and quantification of lycopene from tomato cultivated in Dezfoul, Iran. Jundishapur Journal Natural Pharmaceutical Products, 2011(01, Winter), 9-15.

Alecu, I., Zheng, J., Zhao, Y., \& Truhlar, D. G. (2010). Computational thermochemistry: Scale factor databases and scale factors for vibrational frequencies obtained from electronic model chemistries. Journal of Chemical Theory and Computation, 6(9), 2872-2887.

Amorim, A. G. N., Ropke, C. D., \& Leite, J. R. S. A. (2016). Brazil Patent No. BR102016030594-2. Instituto Nacional de Propriedade Intelectual (INPI).

Arathi, B. P., Sowmya, P. R. R., Vijay, K., Dilshad, P., Saikat, B., Gopal, V., \& Lakshminarayana, R. (2015). An improved method of UPLC-PDA-MS/MS analysis of lycopene isomers. Food Analytical Methods, 8(8), 1962-1969.

Bandeira, A. C. B., da Silva, R. C., Rossoni, J. V., Figueiredo, V. P., Talvani, A., Cangussú, S. D., ... Costa, D. C. (2017). Lycopene pretreatment improves hepatotoxicity induced by acetaminophen in C57BL/6 mice. Bioorganic \& Medicinal Chemistry, 25(3), 1057-1065.

Baranska, M., Schütze, W., \& Schulz, H. (2006). Determination of lycopene and $\beta$-carotene content in tomato fruits and related products: Comparison of FT-Raman, ATRIR, and NIR spectroscopy. Analytical Chemistry, 78(24), 8456-8461.

Bento, R., Freire, P., Teixeira, A., Silva, J., Lima, J., Jr., de Oliveira, M., ... Pontes, F. (2009). Vibrational spectra of pilocarpine hydrochloride crystals. Brazilian Journal of Physics, 39(1), 62-68.

Bertoli, C., Skotheim, J. M., \& De Bruin, R. A. (2013). Control of cell cycle transcription during G1 and S phases. Nature Reviews. Molecular Cell Biology, 14(8), 518-528.

Böhm, V. (2012). Lycopene and heart health. Molecular Nutrition \& Food Research, 56(2), 296-303.

Bramley, P. M. (2000). Is lycopene beneficial to human health. Phytochemistry, 54(3), 233-236.

Carvalho, A. C., Márquez, C. A. P., Azevedo, R. B., Joanitti, G. A., Júnior, O. R. P., Fontes, W., \& Castro, M. S. (2015). Cytotoxic activity and antiproliferative effects of crude skin secretion from Physalaemus Nattereri (Anura: Leptodactylidae) on in vitro melanoma cells. Toxins, 7(10), 3989-4005.

Chalabi, N., Delort, L., Le Corre, L., Satih, S., Bignon, Y.-J., \& Bernard-Gallon, D. (2006). Gene signature of breast cancer cell lines treated with lycopene. Pharmacogenomics, $7(5), 663-672$.

Chalabi, N., Le Corre, L., Maurizis, J. C., Bignon, Y., \& Bernard-Gallon, D. (2004). The effects of lycopene on the proliferation of human breast cells and BRCA1 and BRCA2 gene expression. European Journal of Cancer, 40(11), 1768-1775.

Chalabi, N., Satih, S., Delort, L., Bignon, Y.-J., \& Bernard-Gallon, D. J. (2007). Expression profiling by whole-genome microarray hybridization reveals differential gene expression in breast cancer cell lines after lycopene exposure. Biochimica et Biophysica Acta (BBA)-Gene Structure and Expression, 1769(2), 124-130.

Chisté, R. C., Freitas, M., Mercadante, A. Z., \& Fernandes, E. (2014). Carotenoids are effective inhibitors of in vitro hemolysis of human erythrocytes, as determined by a practical and optimized cellular antioxidant assay. Journal of Food Science, 79(9),
$\mathrm{H} 1841-\mathrm{H} 1847$

Choi, H., \& Lee, D. G. (2015). Lycopene induces apoptosis in Candida Albicans through reactive oxygen species production and mitochondrial dysfunction. Biochimie, 115, 108-115.

Cunha, V. R., Izumi, C. M., Petersen, P. A., Magalhaes, A., Temperini, M. L., Petrilli, H. M., \& Constantino, V. R. (2014). Mefenamic acid anti-inflammatory drug: Probing its polymorphs by vibrational (IR and Raman) and solid-state NMR spectroscopies. The Journal of Physical Chemistry B, 118(16), 4333-4344.

Cunha, V. R., Petersen, P. A., Goncalves, M. B., Petrilli, H. M., Taviot-Gueho, C., Leroux, F., ... Constantino, V. R. (2012). Structural, spectroscopic (NMR, IR, and Raman), and DFT investigation of the self-assembled nanostructure of pravastatin-LDH (layered double hydroxides) systems. Chemistry of Materials, 24(8), 1415-1425.

Dalla Nora, C., Jablonski, A., Rios, A.d. O., Hertz, P. F., Jong, E. V., \& Flôres, S. H. (2014) The characterisation and profile of the bioactive compounds in red guava (Psidium cattleyanum Sabine) and guabiju (Myrcianthes Pungens (O. Berg) D. Legrand). International Journal of Food Science and Technology, 49(8), 1842-1849.

De Nardo, T., Shiroma-Kian, C., Halim, Y., Francis, D., \& Rodriguez-Saona, L. E. (2009). Rapid and simultaneous determination of lycopene and $\beta$-carotene contents in tomato juice by infrared spectroscopy. Journal of Agricultural and Food Chemistry, 57(4), 1105-1112.

DeSantis, C. E., Lin, C. C., Mariotto, A. B., Siegel, R. L., Stein, K. D., Kramer, J. L., ... Jemal, A. (2014). Cancer treatment and survivorship statistics, 2014. CA: a Cancer Journal for Clinicians, 64(4), 252-271.

Di Mascio, P., Kaiser, S., \& Sies, H. (1989). Lycopene as the most efficient biological carotenoid singlet oxygen quencher. Archives of Biochemistry and Biophysics, 274(2), 532-538.

Dive, C., Gregory, C. D., Phipps, D. J., Evans, D. L., Milner, A. E., \& Wyllie, A. H. (1992) Analysis and discrimination of necrosis and apoptosis (programmed cell death) by multiparameter flow cytometry. Biochimica et Biophysica Acta (BBA)-Molecular Cell Research, 1133(3), 275-285.

Dong, L., Shion, H., Davis, R. G., Terry-Penak, B., Castro-Perez, J., \& Van Breemen, R. B. (2010). Collision cross-section determination and tandem mass spectrometric analysis of isomeric carotenoids using electrospray ion mobility time-of-flight mass spectrometry. Analytical Chemistry, 82(21), 9014-9021.

Frisch, M., Trucks, G., Schlegel, H., Scuseria, G., Robb, M., Cheeseman, J., ... Petersson, G. (2009). Gaussian 09, Revision D. 01. Wallingford CT: Gaussian, Inc.

Ganesh, N. S., Lakshmi, K. B., \& Chandy, V. (2016). Lycopene properties and it's benefits in human health: A brief review. World Journal of Pharmacy and Pharmaceutical Sciences, 5(12), 424-436.

Giusti, M. M., Atnip, A., Sweeney, C., \& Rodriguez-Saona, L. E. (2011). Rapid authentication of fruit juices by infrared spectroscopic techniques. Progress in Authentication of Food and Wine (pp. 275-299). ACS Publications.

Gloria, N. F., Soares, N., Brand, C., Oliveira, F. L., Borojevic, R., \& Teodoro, A. J. (2014) Lycopene and beta-carotene induce cell-cycle arrest and apoptosis in human breast cancer cell lines. Anticancer Research, 34(3), 1377-1386.

Honda, M., Takahashi, N., Kuwa, T., Takehara, M., Inoue, Y., \& Kumagai, T. (2015) Spectral characterisation of Z-isomers of lycopene formed during heat treatment and solvent effects on the E/Z isomerisation process. Food Chemistry, 171, 323-329.

Hu, W., Wang, H., Liu, Z., Liu, Y., Wang, R., Luo, X., \& Huang, Y. (2017). Neuroprotective effects of lycopene in spinal cord injury in rats via antioxidative and anti-apoptotic pathway. Neuroscience Letters, 642, 107-112.

Jain, M. V., Paczulla, A. M., Klonisch, T., Dimgba, F. N., Rao, S. B., Roberg, K., , Palicharla, V. R. (2013). Interconnections between apoptotic, autophagic and necrotic pathways: Implications for cancer therapy development. Journal of Cellular and Molecular Medicine, 17(1), 12-29.

Joanitti, G. A., Azevedo, R. B., \& Freitas, S. M. (2010). Apoptosis and lysosome membrane permeabilization induction on breast cancer cells by an anticarcinogenic Bowman-Birk protease inhibitor from Vigna Unguiculata seeds. Cancer Letters, 293(1), 73-81.

Kim, S. W., Ahn, M. S., Kwon, Y. K., Song, S. Y., Kim, J. K., Ha, S.-H., ... Liu, J. R. (2015). Monthly metabolic changes and PLS prediction of carotenoid content of citrus fruit by combined Fourier transform infrared spectroscopy and quantitative HPLC analysis. Plant Biotechnology Reports, 9(4), 247-258.

King-Batoon, A., Leszczynska, J. M., \& Klein, C. B. (2008). Modulation of gene methylation by genistein or lycopene in breast cancer cells. Environmental and Molecular Mutagenesis, 49(1), 36-45.

Lee, C., Yang, W., \& Parr, R. G. (1988). Development of the Colle-Salvetti correlationenergy formula into a functional of the electron density. Physical Review B, 37(2), 785-789.

Lee, S., Choi, H.-K., Cho, S. K., \& Kim, Y.-S. (2010). Metabolic analysis of guava (Psidium Guajava L.) fruits at different ripening stages using different data-processing approaches. Journal of Chromatography B, 878(29), 2983-2988.

Lee, S.-B., \& Park, H.-R. (2010). Anticancer activity of guava (Psidium Guajava L.) branch extracts against HT-29 human colon cancer cells. Journal of Medicinal Plant Research, 4(10), 891-896.

Levy, J., Bosin, E., Feldman, B., Giat, Y., Miinster, A., Danilenko, M., \& Sharoni, Y. (1995). Lycopene is a more potent inhibitor of human cancer cell proliferation than either $\alpha$ carotene or $\beta$-carotene. Nutrition and Cancer, 24(3), 257-266.

Mangels, A. R., Holden, J. M., Beecher, G. R., Forman, M. R., \& Lanza, E. (1993). Carotenoid content of fruits and vegetables: An evaluation of analytic data. Journal of the American Dietetic Association, 93(3), 284-296.

Marenich, A. V., Ho, J., Coote, M. L., Cramer, C. J., \& Truhlar, D. G. (2014). Computational electrochemistry: Prediction of liquid-phase reduction potentials. Physical Chemistry Chemical Physics, 16(29), 15068-15106.

Mariani, S., Lionetto, L., Cavallari, M., Tubaro, A., Rasio, D., De Nunzio, C., ... Simmaco, M. (2014). Low prostate concentration of lycopene is associated with development of 
prostate cancer in patients with high-grade prostatic intraepithelial neoplasia. International Journal of Molecular Sciences, 15(1), 1433-1440.

Obermüller-Jevic, U. C., Olano-Martin, E., Corbacho, A. M., Eiserich, J. P., Van der Vliet, A., Valacchi, G., ... Packer, L. (2003). Lycopene inhibits the growth of normal human prostate epithelial cells in vitro. The Journal of Nutrition, 133(11), 3356-3360.

Ojha, S., Goyal, S., Sharma, C., Arora, S., Kumari, S., \& Arya, D. (2013). Cardioprotective effect of lycopene against isoproterenol-induced myocardial infarction in rats. Human \& Experimental Toxicology, 32(5), 492-503.

Oliveira, D. D. S., Lobato, A. L., Ribeiro, S. M. R., Santana, Â. M. C., Chaves, J. B. P., \& Pinheiro-Sant'Ana, H. M. (2010). Carotenoids and vitamin C during handling and distribution of guava (Psidium Guajava L.), mango (Mangifera Indica L.), and papaya (Carica Papaya L.) at commercial restaurants. Journal of Agricultural and Food Chemistry, 58(10), 6166-6172.

Peng, S., Li, J., Zhou, Y., Tuo, M., Qin, X., Yu, Q., ... Li, Y. (2017). In vitro effects and mechanisms of lycopene in MCF-7 human breast cancer cells. Genetics and molecular research: GMR, 16(2), 1-8.

Pinto, C., Rodríguez-Galdón, B., Cestero, J. J., \& Macías, P. (2013). Hepatoprotective effects of lycopene against carbon tetrachloride-induced acute liver injury in rats. Journal of Functional Foods, 5(4), 1601-1610.

Reddy, M. K., Alexander-Lindo, R. L., \& Nair, M. G. (2005). Relative inhibition of lipid peroxidation, cyclooxygenase enzymes, and human tumor cell proliferation by natural food colors. Journal of Agricultural and Food Chemistry, 53(23), 9268-9273.

Rocha, M. A., Petersen, P. A., Teixeira-Neto, E., Petrilli, H. M., Leroux, F., Taviot-Gueho, C., \& Constantino, V. R. (2016). Layered double hydroxide and sulindac coiled and scrolled nanoassemblies for storage and drug release. RSC Advances, 6(20), 16419-16436.

Ronot, X., Benel, L., Adolphe, M., \& Mounolou, J. (1986). Mitochondrial analysis in living cells: The use of rhodamine 123 and flow cytometry. Biology of the Cell, 57(1), 1-7.

Ryu, N. H., Park, K.-R., Kim, S.-M., Yun, H.-M., Nam, D., Lee, S.-G., ... Shim, B. S. (2012). A hexane fraction of guava leaves (Psidium Guajava L.) induces anticancer activity by suppressing AKT/mammalian target of rapamycin/ribosomal p70 S6 kinase in human prostate cancer cells. Journal of Medicinal Food, 15(3), 231-241.

Shen, C., Wang, S., Shan, Y., Liu, Z., Fan, F., Tao, L., ... Wu, H. (2014). Chemomodulatory efficacy of lycopene on antioxidant enzymes and carcinogen-induced cutaneum carcinoma in mice. Food \& Function, 5(7), 1422-1431.

Śliwka, L., Wiktorska, K., Suchocki, P., Milczarek, M., Mielczarek, S., Lubelska, K., ... Jaromin, A. (2016). The comparison of MTT and CVS assays for the assessment of anticancer agent interactions. PLoS One, 11(5), e0155772.

Srivastava, S., \& Srivastava, A. K. (2015). Lycopene; chemistry, biosynthesis, metabolism and degradation under various abiotic parameters. Journal of Food Science and Technology, 52(1), 41-53.

Stinco, C. M., Rodríguez-Pulido, F. J., Escudero-Gilete, M. L., Gordillo, B., Vicario, I. M., \& Meléndez-Martínez, A. J. (2013). Lycopene isomers in fresh and processed tomato products: Correlations with instrumental color measurements by digital image analysis and spectroradiometry. Food Research International, 50(1), 111-120.

Takeshima, M., Ono, M., Higuchi, T., Chen, C., Hara, T., \& Nakano, S. (2014). Antiproliferative and apoptosis-inducing activity of lycopene against three subtypes of human breast cancer cell lines. Cancer Science, 105(3), 252-257.

Teodoro, A. J., Oliveira, F. L., Martins, N. B., de Azevedo Maia, G., Martucci, R. B., \& Borojevic, R. (2012). Effect of lycopene on cell viability and cell cycle progression in human cancer cell lines. Cancer Cell International, 12(1), 36.

Trebolazabala, J., Maguregui, M., Morillas, H., de Diego, A., \& Madariaga, J. M. (2017) Portable Raman spectroscopy for an in-situ monitoring the ripening of tomato (Solanum Lycopersicum) fruits. Spectrochimica Acta Part A: Molecular and Biomolecular Spectroscopy, 180, 138-143.

Uppala, P. T., Dissmore, T., Lau, B. H., Andacht, T., \& Rajaram, S. (2013). Selective inhibition of cell proliferation by lycopene in MCF-7 breast cancer cells in vitro: A proteomic analysis. Phytotherapy Research, 27(4), 595-601.

Vargas-Murga, L., de Rosso, V. V., Mercadante, A. Z., \& Olmedilla-Alonso, B. (2016). Fruits and vegetables in the Brazilian household budget survey (2008-2009): Carotenoid content and assessment of individual carotenoid intake. Journal of Food Composition and Analysis, 50, 88-96.

Vasconcelos, A. G., das GN Amorim, A., dos Santos, R. C., Souza, J. M. T., de Souza, L. K. M., de SL Araújo, T., ... da Silva Martins, C. (2017). Lycopene rich extract from red guava (Psidium guajava L.) displays anti-inflammatory and antioxidant profile by reducing suggestive hallmarks of acute inflammatory response in mice. Food Research International, 99(2), 959-968

Véras, L. M., Cunha, V. R., Lima, F. C., Guimarães, M. A., Vieira, M. M., Campelo, Y. D., Ellena, J. A. (2013). Industrial scale isolation, structural and spectroscopic characterization of epiisopiloturine from Pilocarpus Microphyllus stapf leaves: A promising alkaloid against schistosomiasis. PLoS One, 8(6), e66702.

Yalvac, M. F, Ramazanoglu, M., Gumru, O. Z, Sahin, F., Palotás, A., \& Rizvanov, A. A. (2009). Comparison and optimisation of transfection of human dental follicle cells, novel source of stem cells, with different chemical methods and electro-poration. Neurochemical Research, 34(7), 1272-1277.

Yang, Y.-J., Qi, S.-N., Shi, R.-Y., Yao, J., Wang, L.-S., Yuan, H.-Q., \& Jing, Y.-X. (2017) Induction of apoptotic DNA fragmentation mediated by mitochondrial pathway with caspase-3-dependent BID cleavage in human gastric cancer cells by a new nitroxyl spin-labeled derivative of podophyllotoxin. Biomedicine \& Pharmacotherapy, 90 , $131-138$. 